
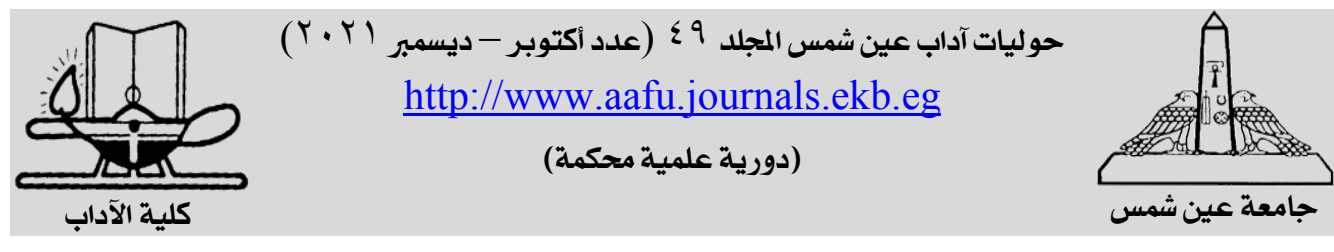

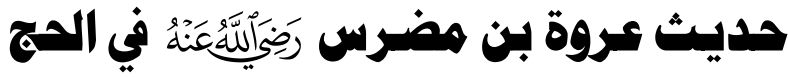

\section{رواية ودرايسة}

* منصور بن محمد الصقعوب

\section{وزارة الثئون الأسلامية}

E-Mail: m0505148411@hotmail.com

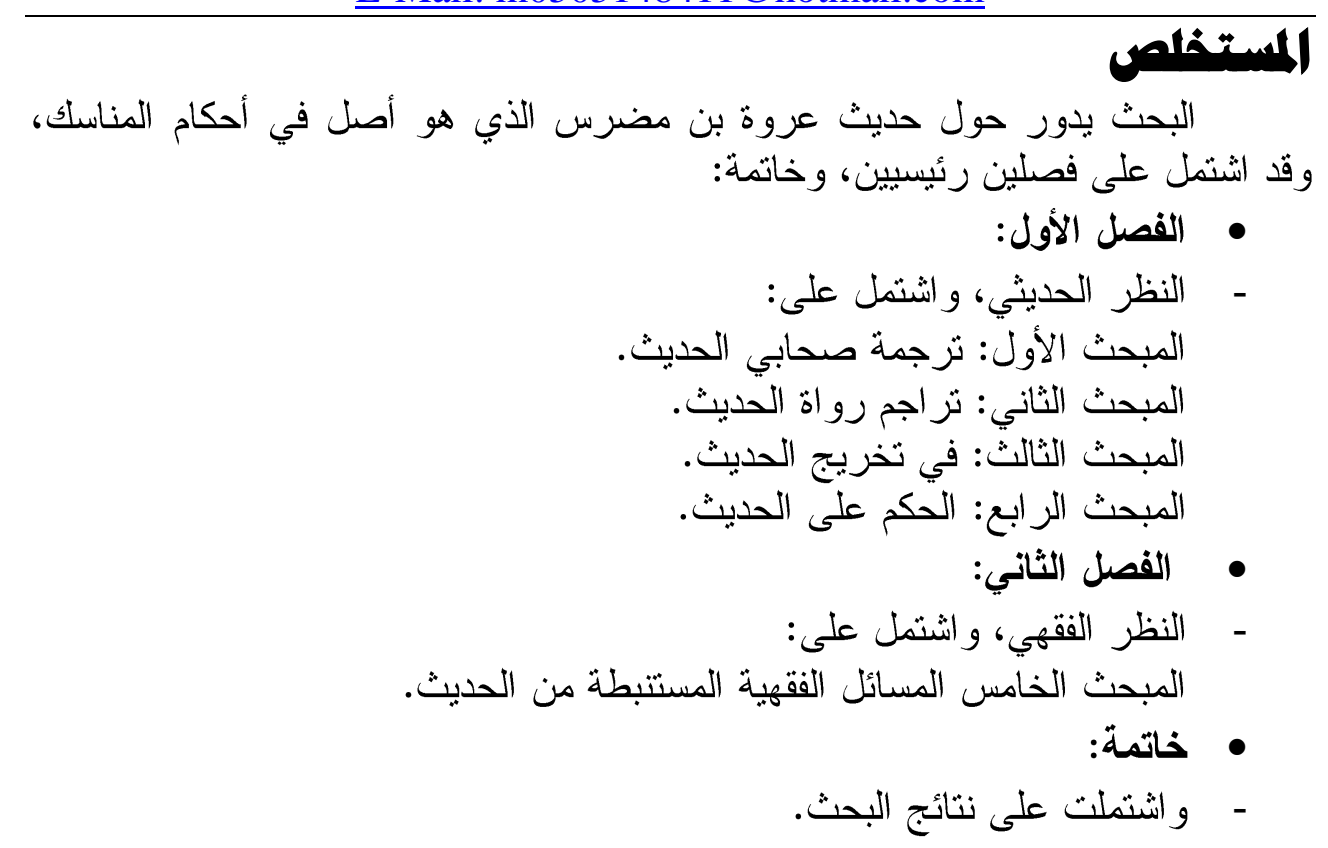




\section{(5)}

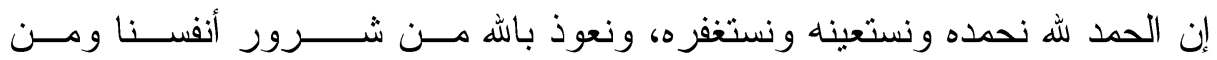

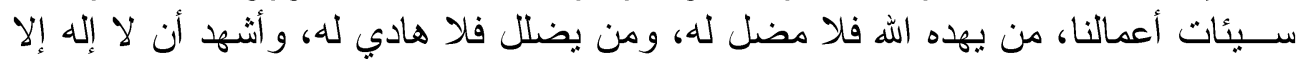
الله وحده لا شــريك له، وأشها، أن محمدأ عبده ورسوله. أما بعد:

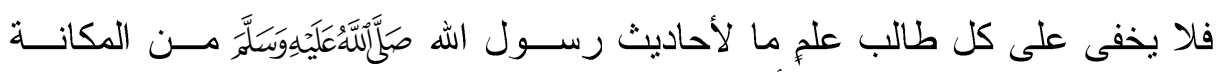

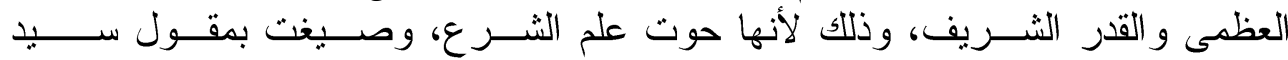

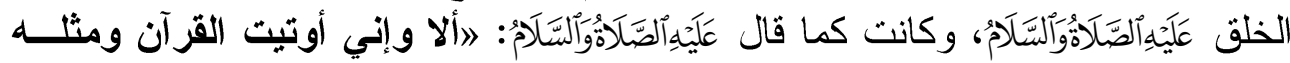

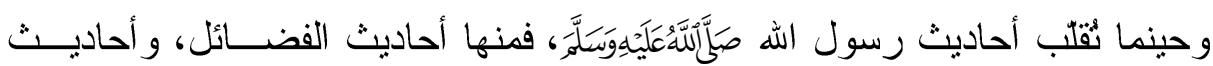

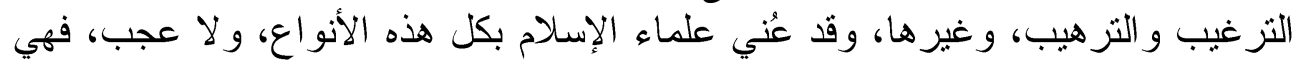

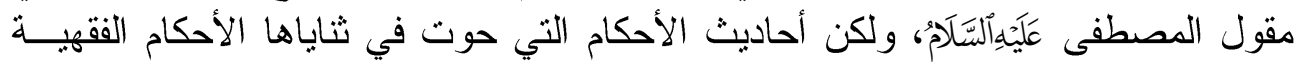

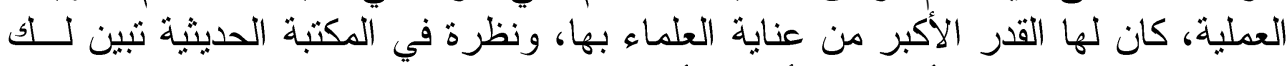
كثرة الكتب التي جمعت أحاديث الأحكام، أو التي شـــرحتها.

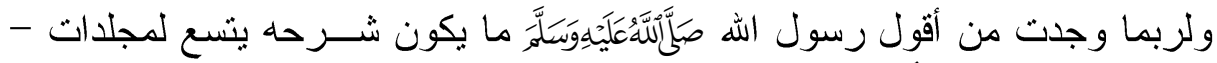

$$
\text { ولا غرابة- فهو قول من أوتي جوام امع الكلم. }
$$

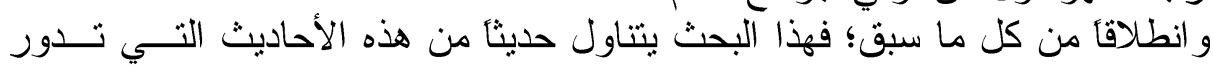

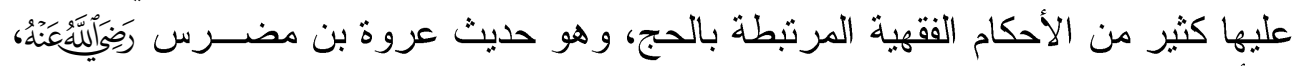

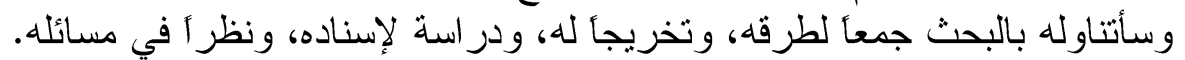

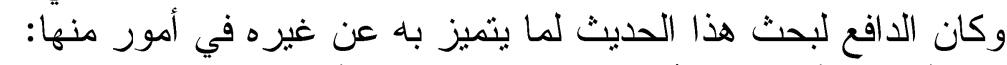

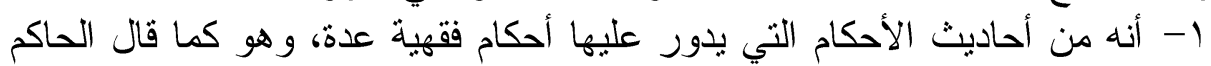

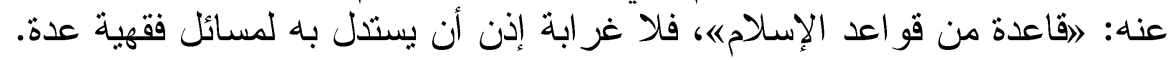

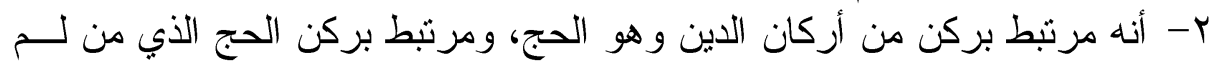

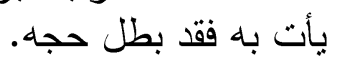

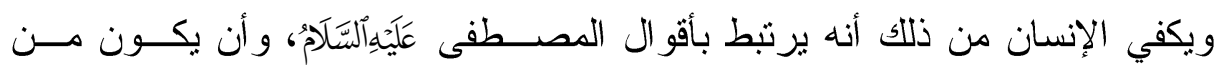

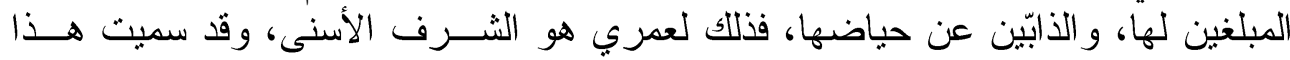

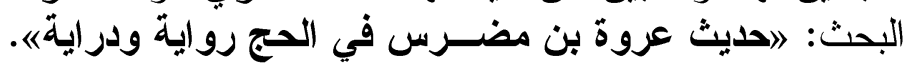
وجعلت خطة هذا البحث كما يلي:

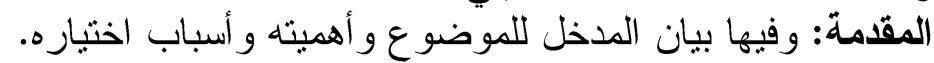

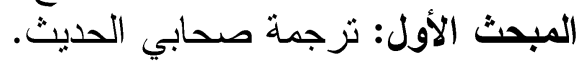
المبحث الثاني: تر اجم رو اة الحديث. المبحث الثالث: في تخريج الحديث. المبحث الرابع: الحكم على الحديث.

المبحث الخامس: المسائل الفقهية المستتبطة من الحديث. 


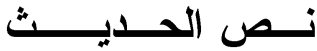

قال أبو داود السجستاني في سننه (90. (190):

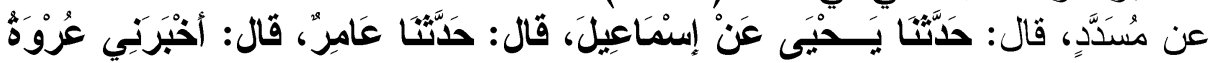

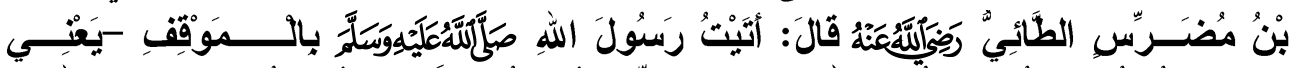

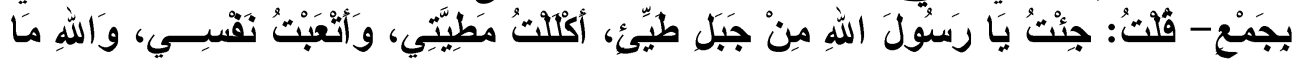

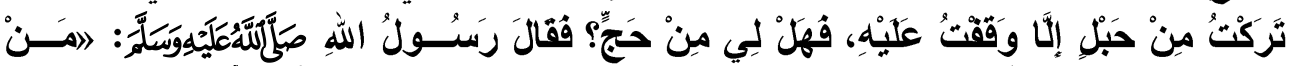

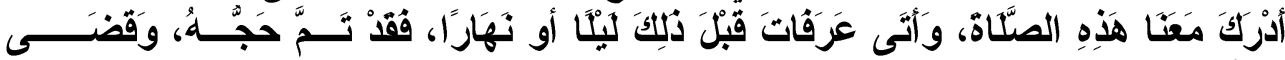

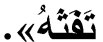




\section{المبحث الأول \\ ترجمة صحابي الحديث}

هو عروة بن مضــرِّ -بمجمة و آخره مهملة وتثنديد الر اء- ابن أوس بن حارثة

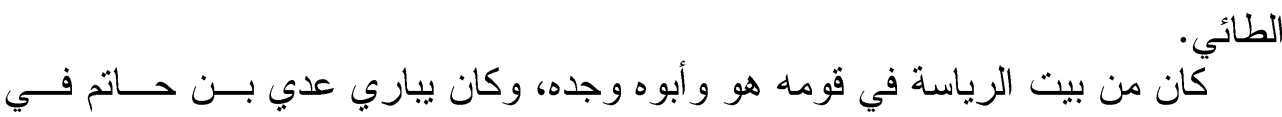

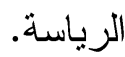

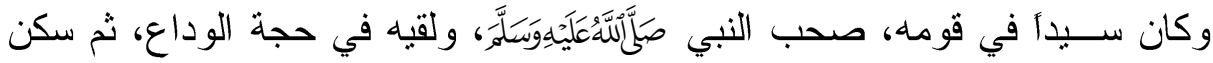

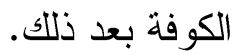

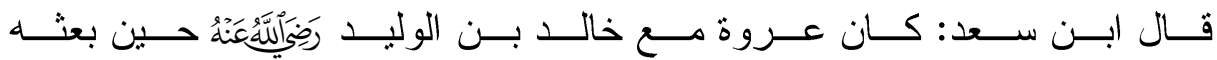

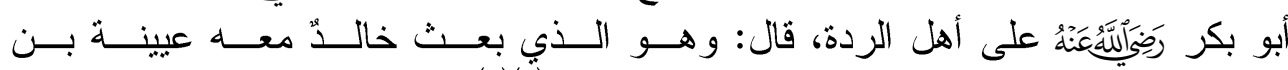

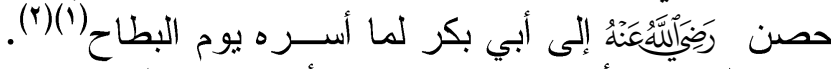

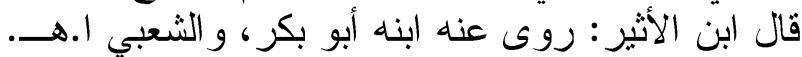
ونقل الحاكم رواية عروة بن الزبير عنه، وسـيـياتي بيانها. 


\section{المبحث الثاني \\ تراجـ رواة الحديث}

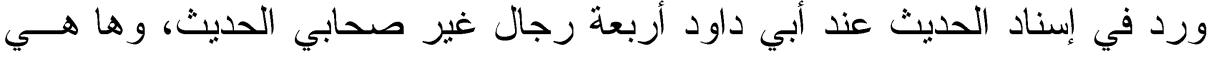
ترجمة كل راو منهم حسب ورودهم في الإسناد.

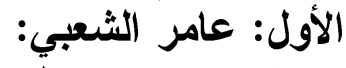

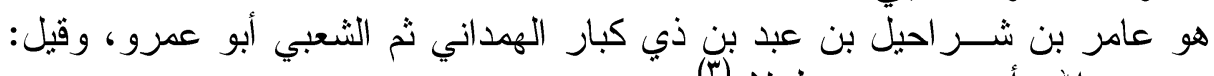

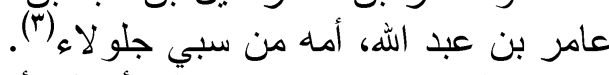
اختلف في سنة و لادته على أقو ال، أشهرها كما قال المزي: أنه ولد لست سنين خلت

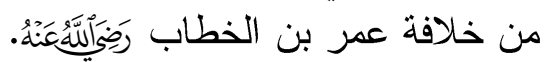
روى عن جمع من الصحأبة، ساق منهم الذهبي خمســين -ثم قال- وغير هـؤلاء

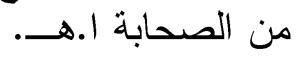

ومن هؤلاء الصحابة: سعد بن أبي وقاص، وسعيد بن زيد، و أبي موسـى، و أبسـي

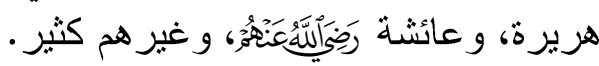

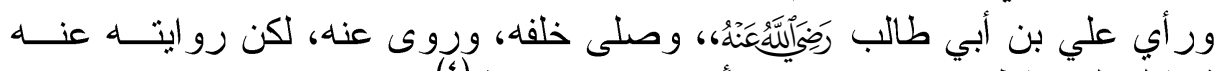

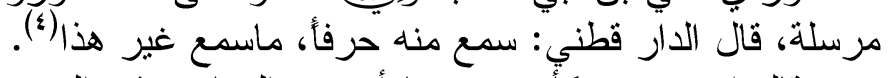

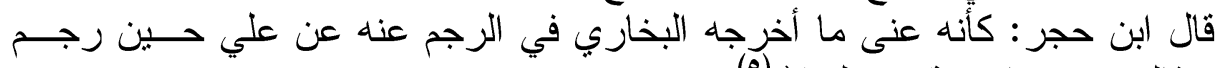

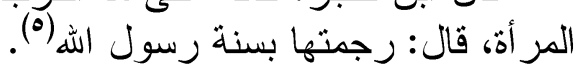

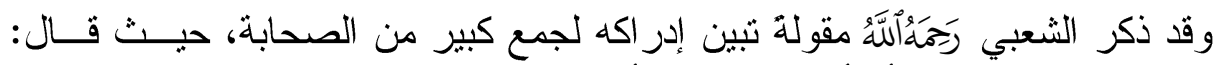

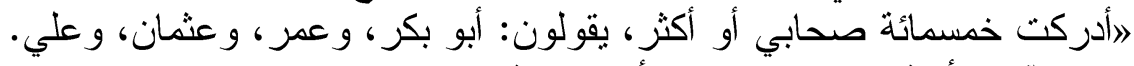

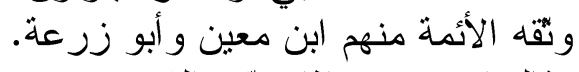

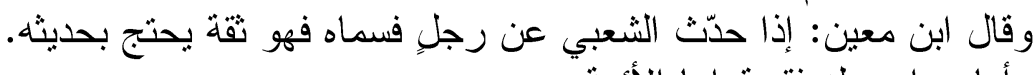
و وأما مر اســبله فقد قو الها الأئمة.

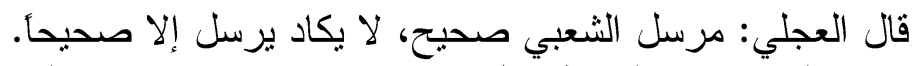

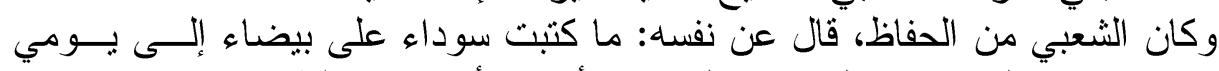

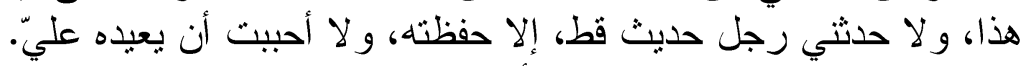

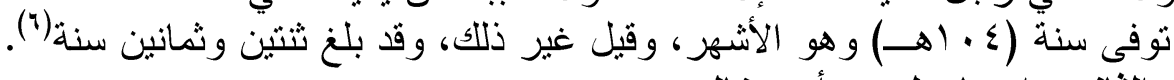

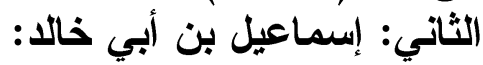

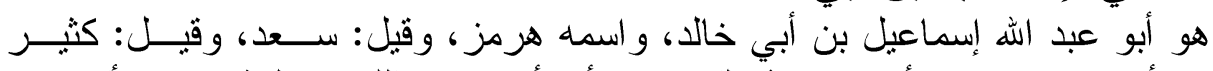

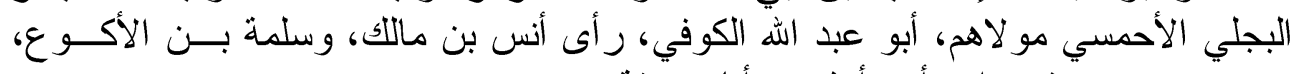

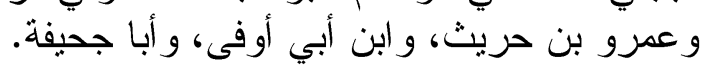

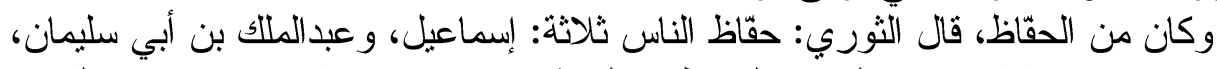

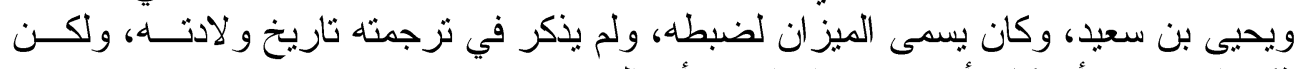
ذكر ابن معين أنه كان أصغر من إير اهيم -أبي النخعي - بسنتنين.

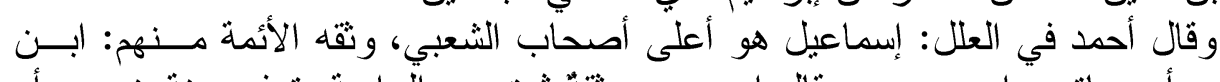

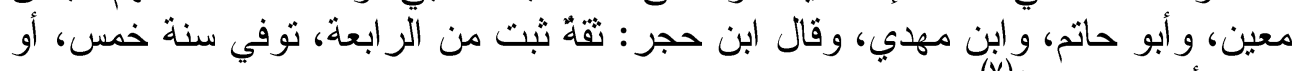

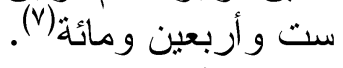

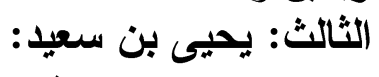

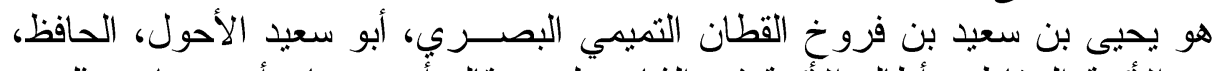

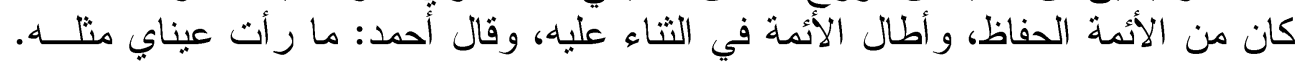




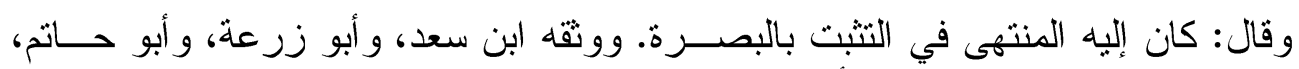

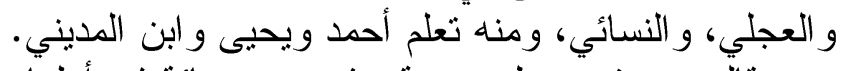

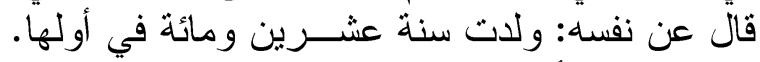

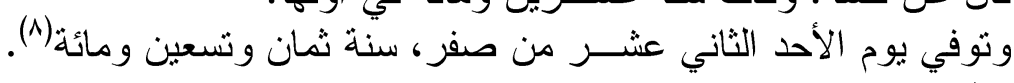

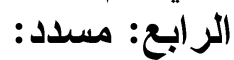

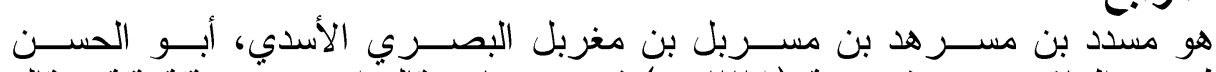

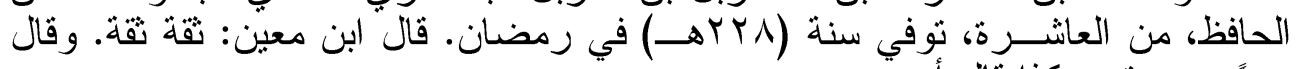

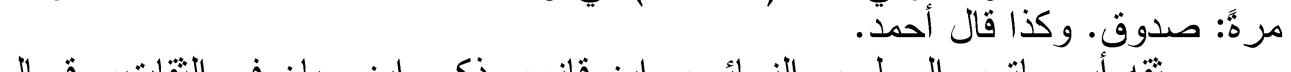
وو وثقه أبو حاتم، و العجلي، و النسائي، و ابن قانع، وذكره ابن حبان في الثقات، وقـال ابن حجر : ثقة حافظ. يقال: أول من صنف المسند بالبصــرة، أخرج له الهـ التزمذي و النسائي، ومن الغر ائب

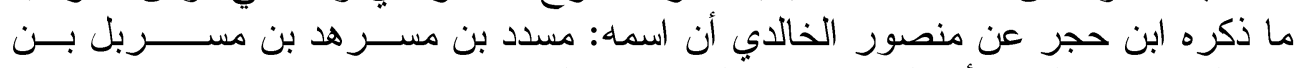

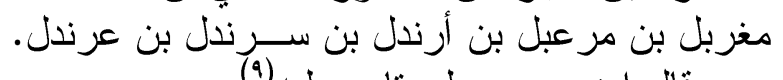

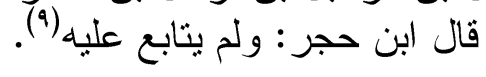




\section{المبحث الثالث \\ تخريج الحديث}

حليث عروة بن مضــرس مداره على عروة بن الزبير ، وقد روي عنه من طريقين.

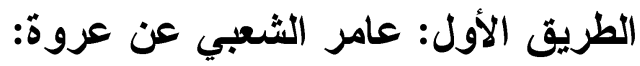

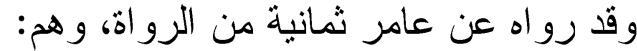

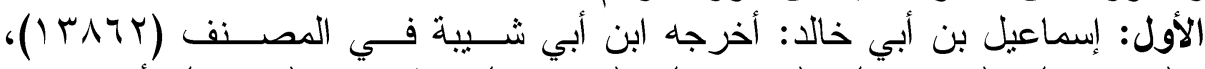

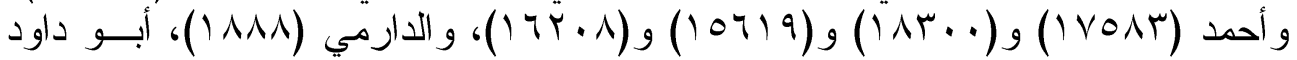

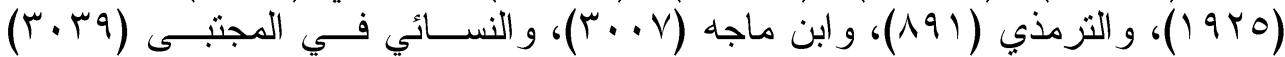

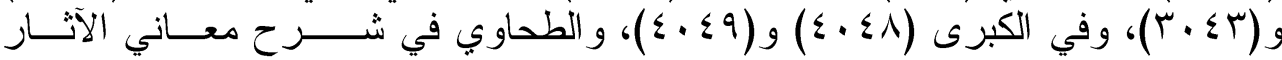

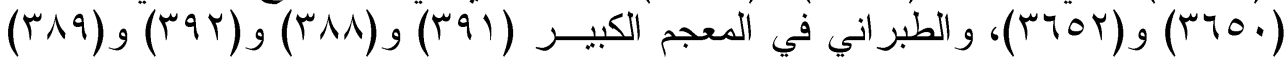

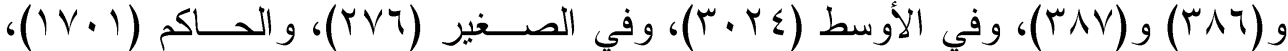

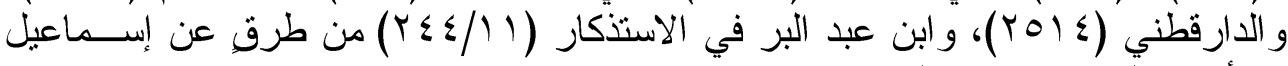

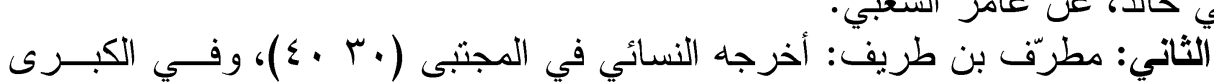

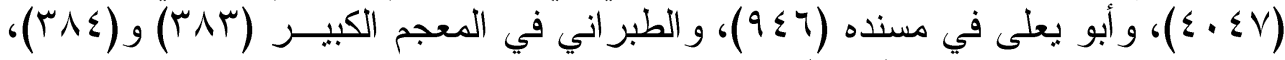

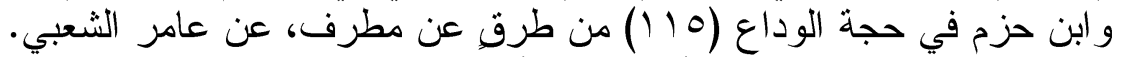

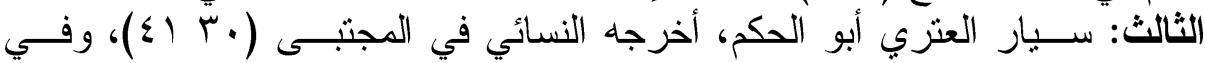

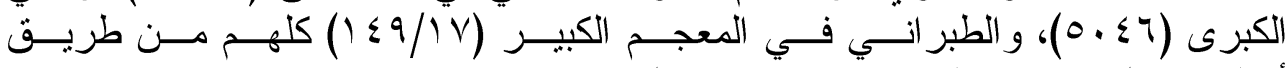

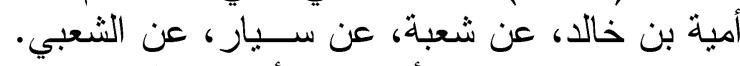

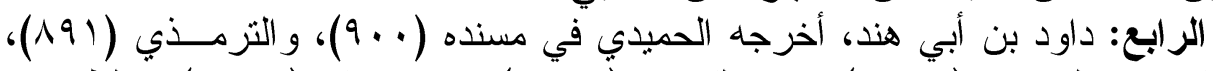

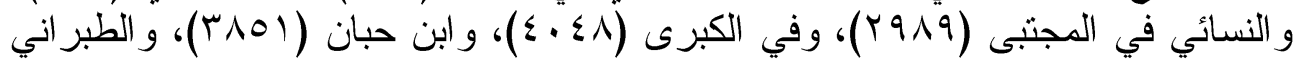

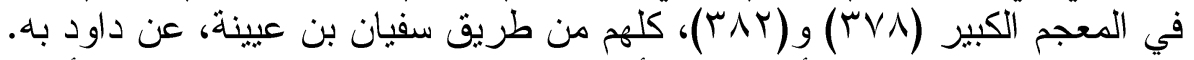

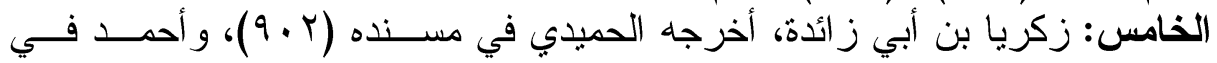

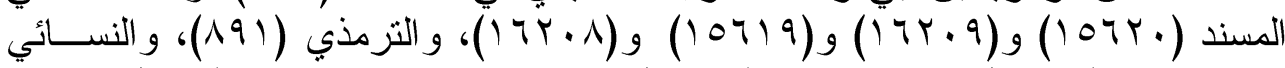

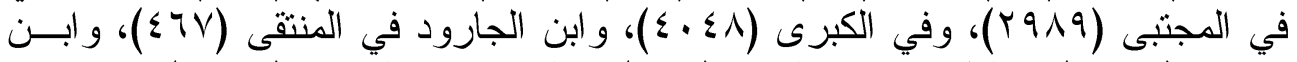

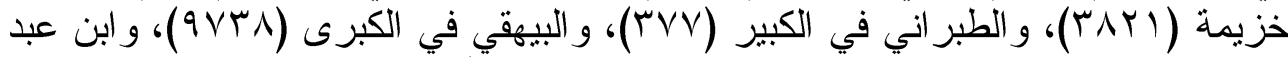

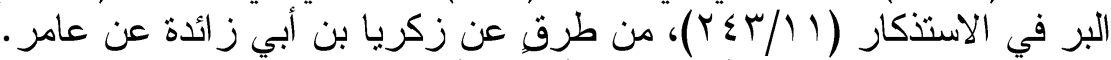

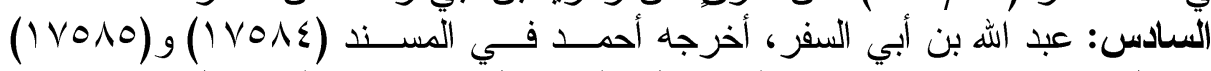

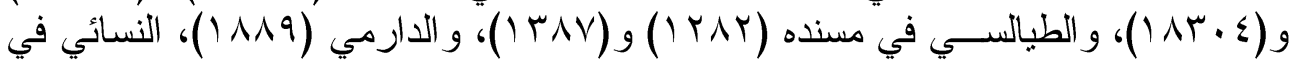

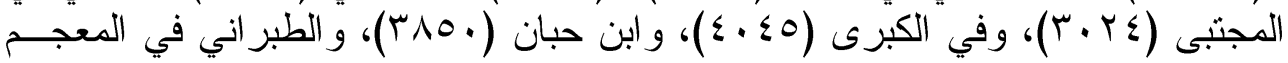

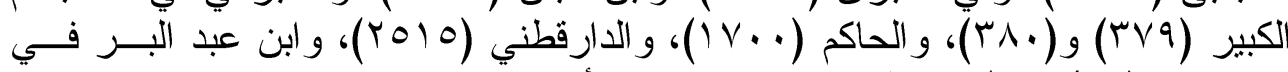

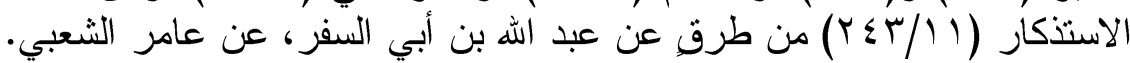

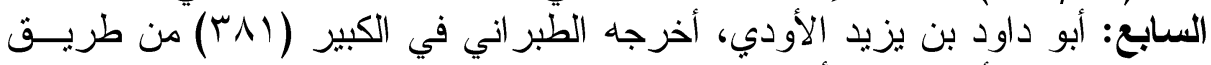

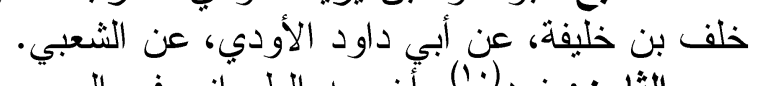

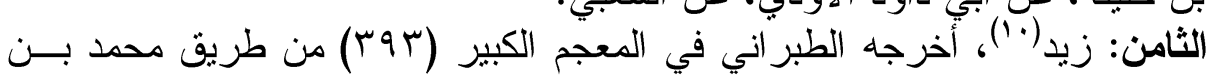

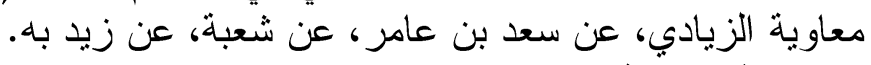

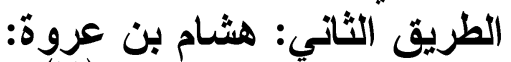

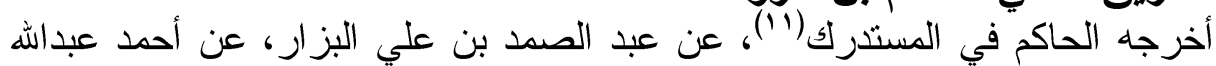

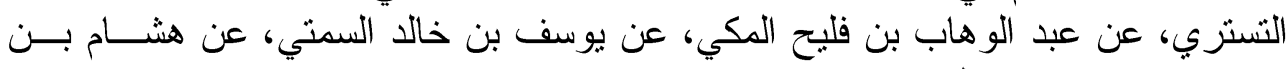
عروة، عن عروة بن الزبير بهاب. 


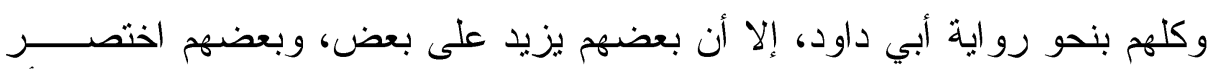

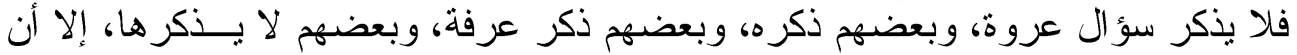

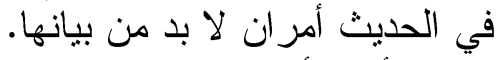

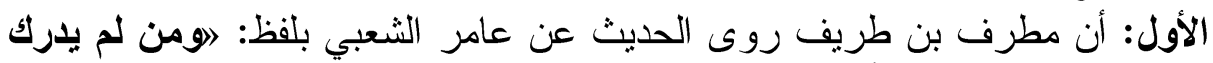

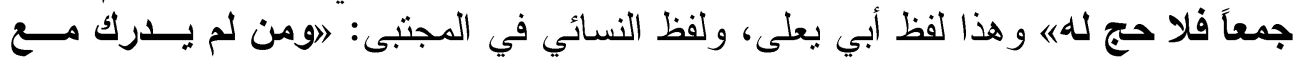

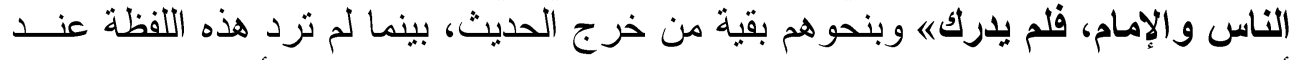

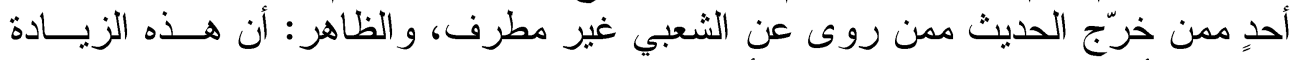

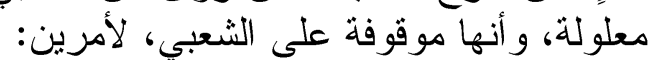

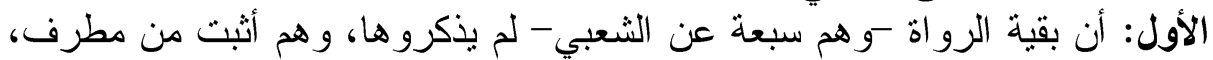

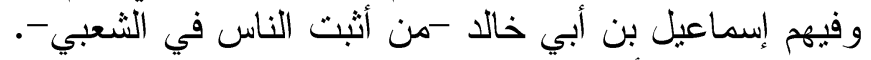

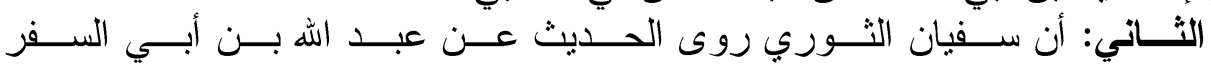

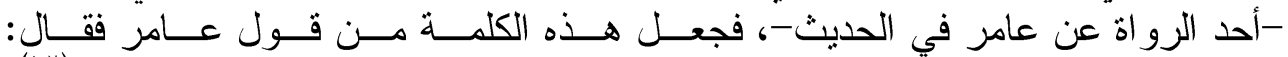

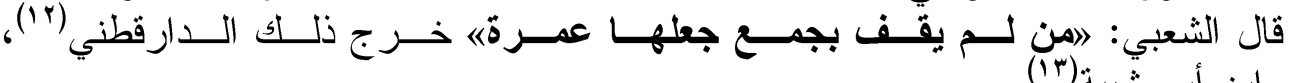

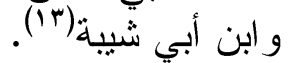

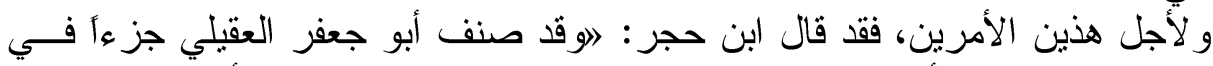

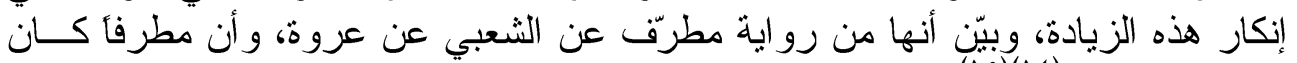

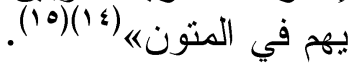
الثاني: أن ابن حبان خرج الحديث عن عروة بن الزبير، وهذه المتابعة لم أجد مسن

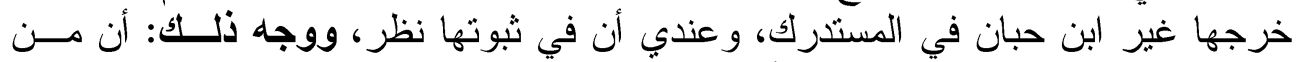

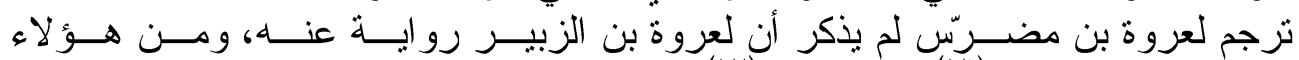

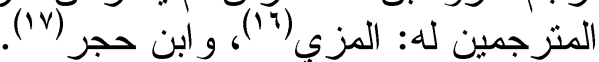

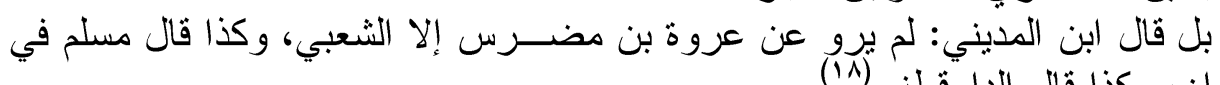

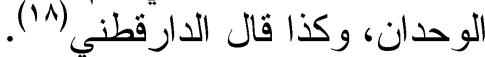

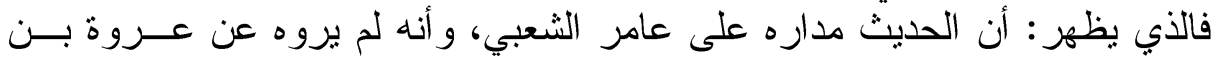

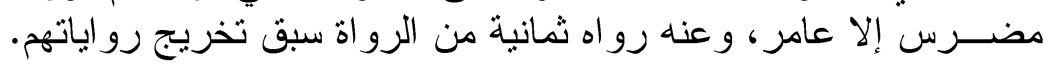




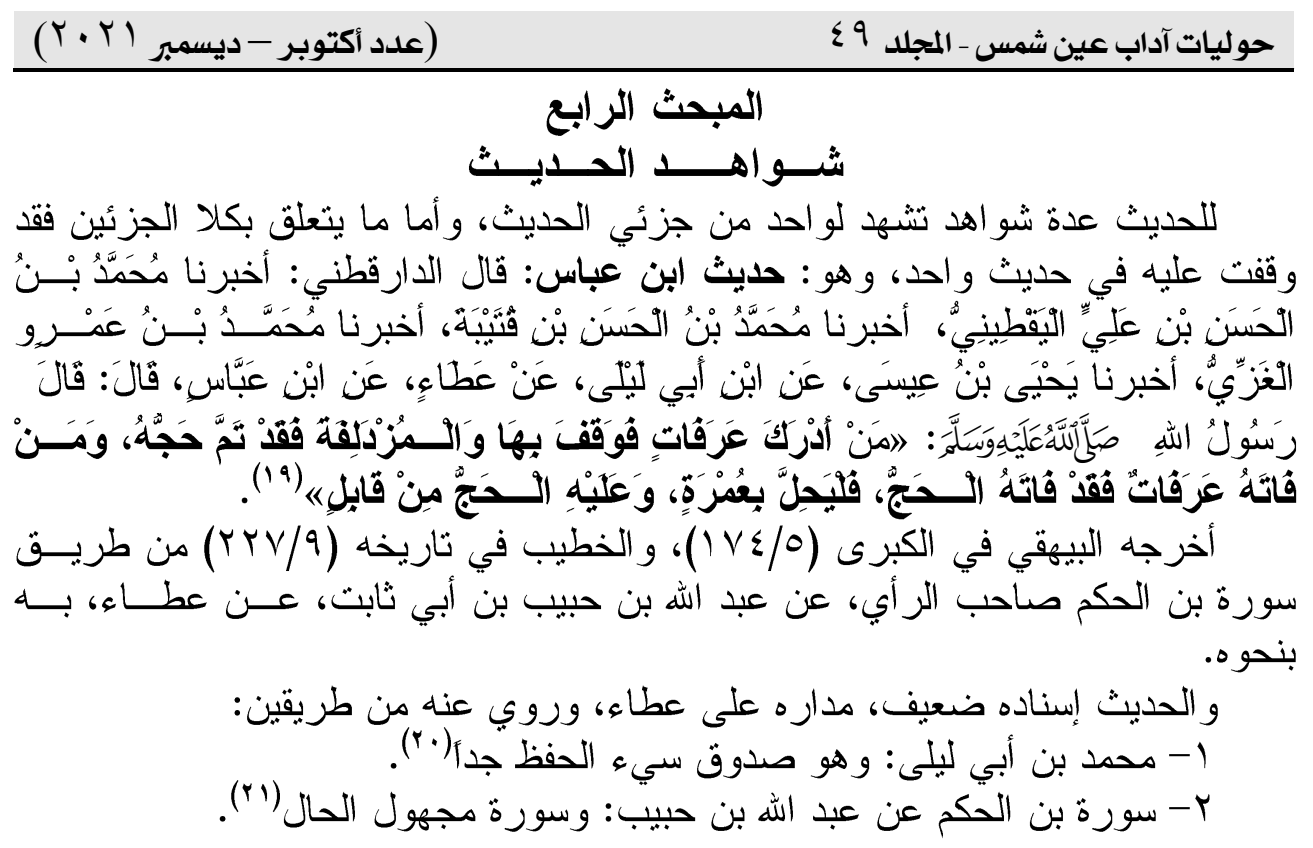




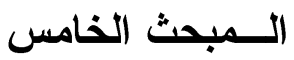

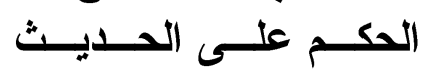

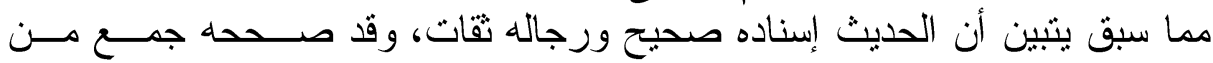

$$
\text { الأئمة، منهم: الزفيق }
$$

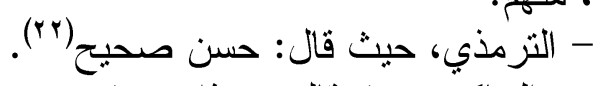

- و الحاكي، حيث قال: الرئ وهذا حديث صحيح عند كافة أئمة الحديث، وهو قاعدة مسن

$$
\text { قو اعد الإسلام (rir). }
$$

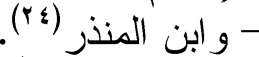

$$
\begin{aligned}
& \text { - و وابن عبد البيز (riv) }
\end{aligned}
$$$$
\text { - و وابن الملقن (ri) - (ri). }
$$

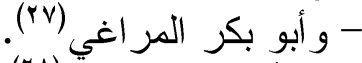

- و الألباني، و وغير هُ (†N) 


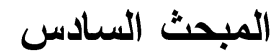

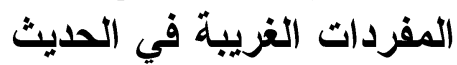

ورد في الحديث ألفاظ تحتاج إلى بيان معناها، وهي حسب ورودها في فـي الحـديث

• بالموقف: كلمة الموقف تطلق على كل موقف يقفه الإنسان، ولذا ورد في الحديث

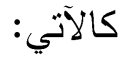

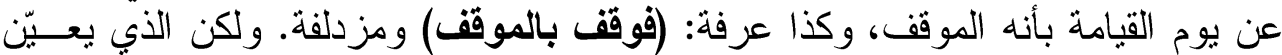

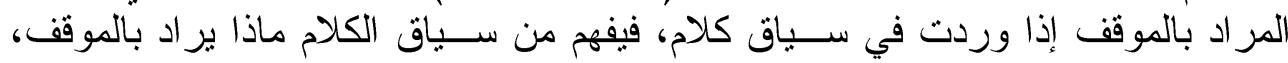
وتكون (ال) للعهد الذكري.

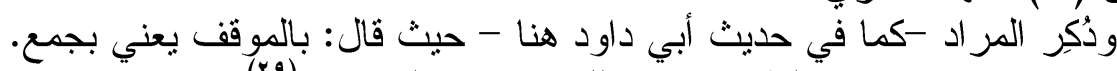

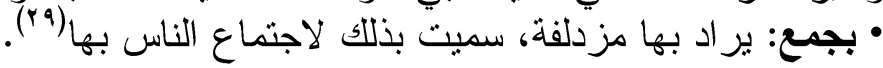

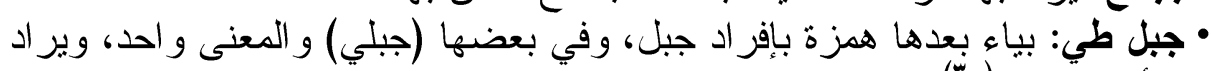

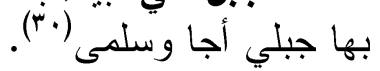
وطي: القبيلة المعروفة، نسكن شمال جزيرة العرب عند الجبلين، جبلي أجا وسلمى. • أكلت: مطيتي: أي أعبيت دابتي و وأتعبنها.

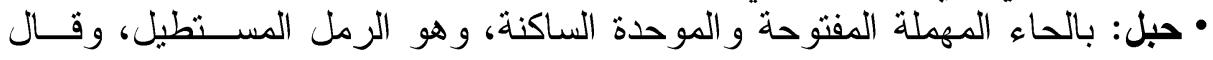

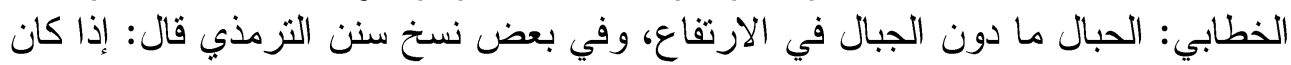

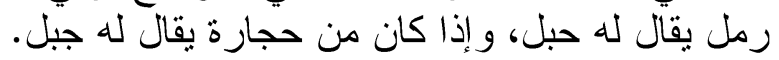
قال العر اقي: المشهور في الرواية فتح الهاء المهملة وسكون الموحدة، أي: (حَبل)،

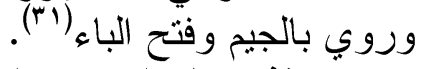

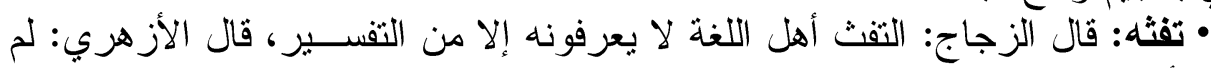

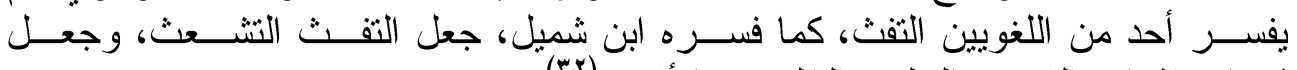

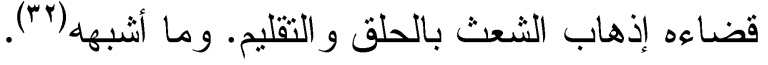

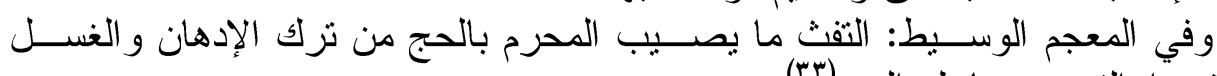

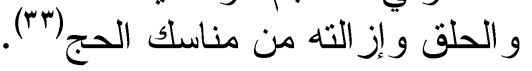




\section{المبحث السابع}

\section{المسائل الفقهية المأخوذة من الحديث}

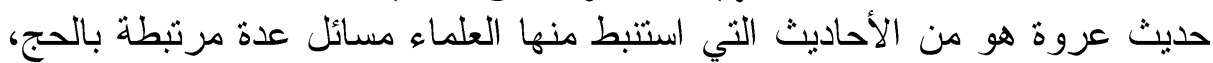

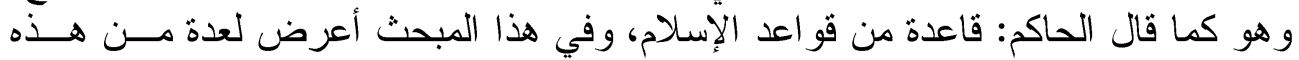

المسائل ومذاهب العلماء فيها.

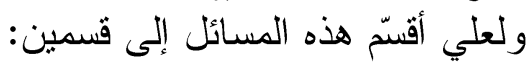

الأول: ما بتعلق بعرفة.

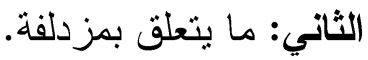




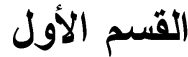 \\ المسائل المتعلقة بعرفة المنة}

$$
\text { المسألة الأولى: الوقوف بعرفة ركن: }
$$

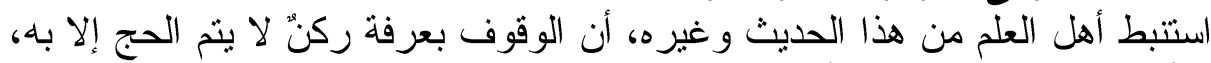
بإجماع أهل العلم، وقد استخلو ا بأدلة منها:

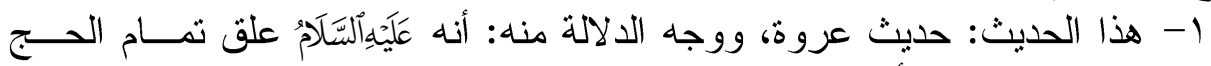

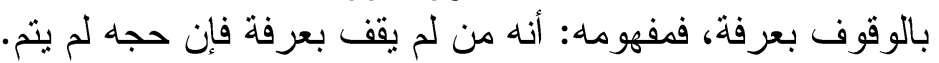

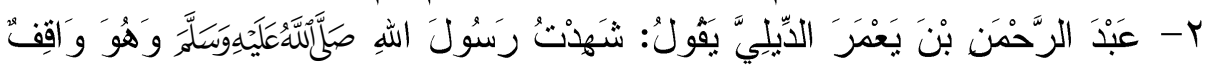

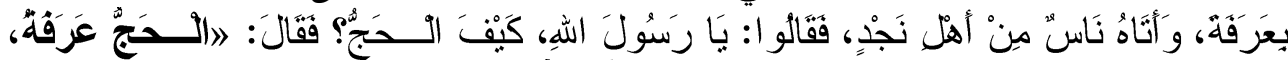

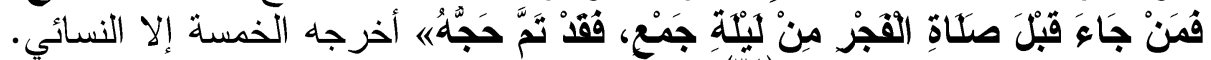

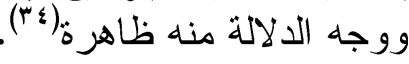

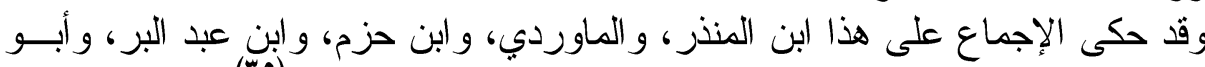

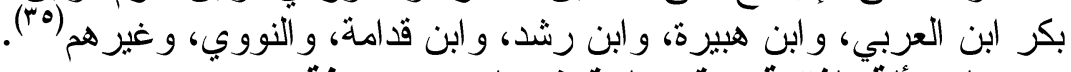

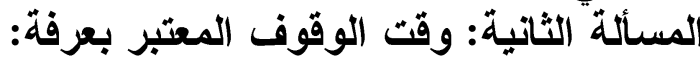

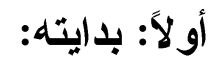
اختلف أهل العلم في بداية الوقوف بعرفة على قولين: القول الأول: أن بداية وقت الوقوف بعرفة بكة يكون من طلوع فجر يوم عرفة، وبه قال

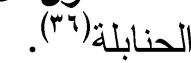

و واستدلوا:

1- بحديث عروة بن مضــرس، وفيه: 》وقد وقف قبل ذلك ليلاً أو نهارآه ومعلومّ

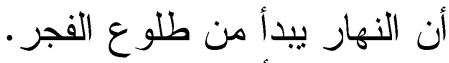

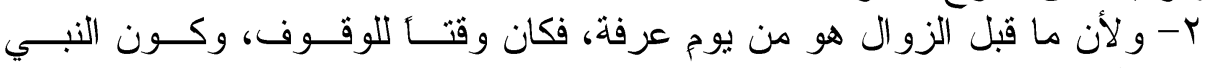

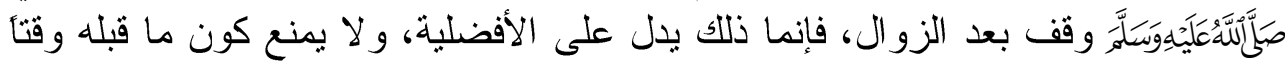

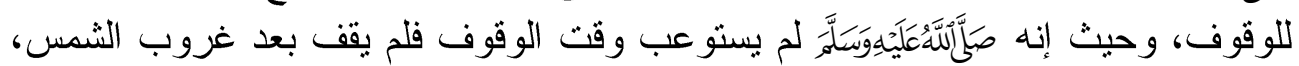

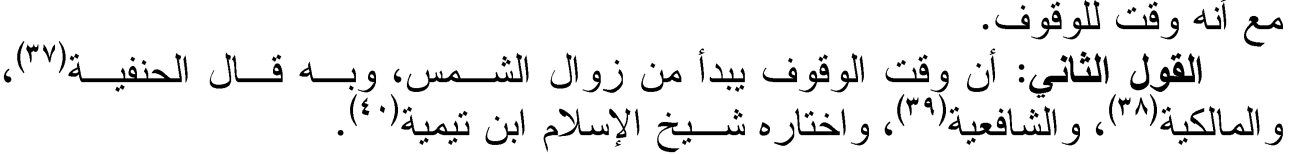

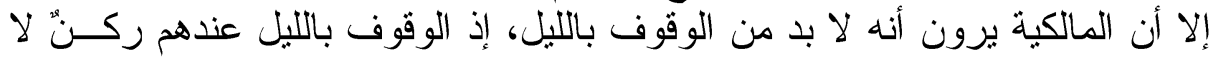

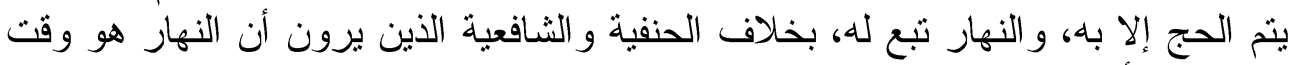

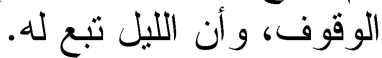
واستدل أصحاب هذا القول بأدلة من أقواها:

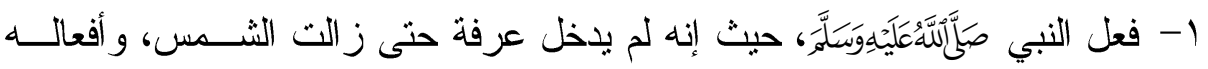

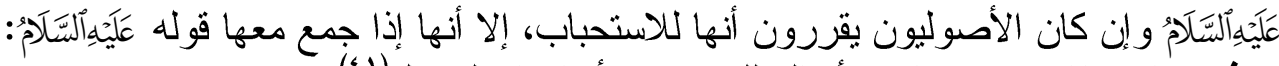

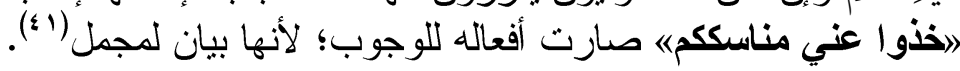

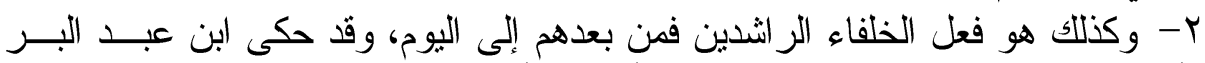

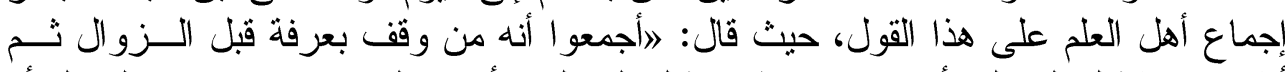

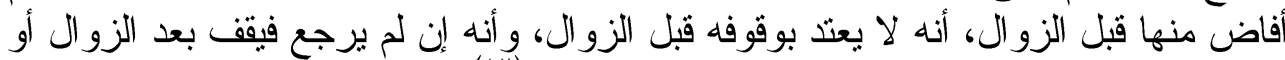

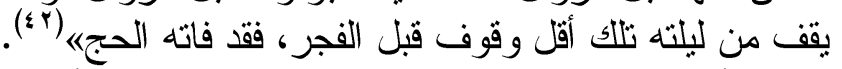
وأجابوا عما استدل به الحنابلة بما خلاصته: أن ما في حديث عروة بن مضــرس 


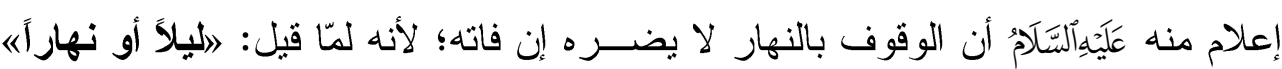

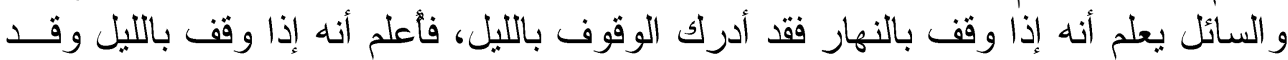

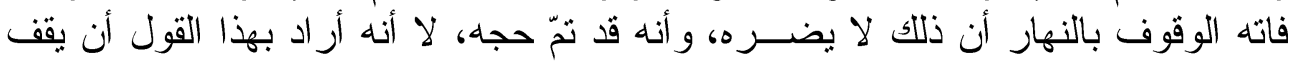

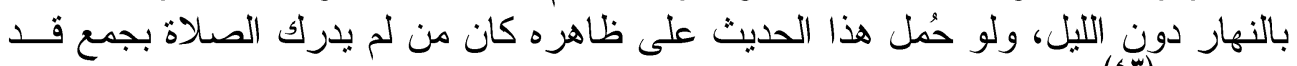

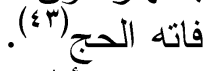

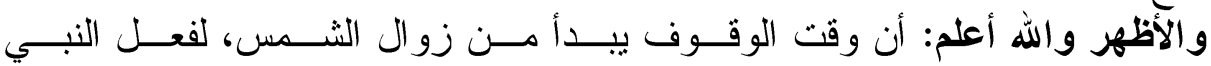

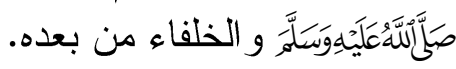

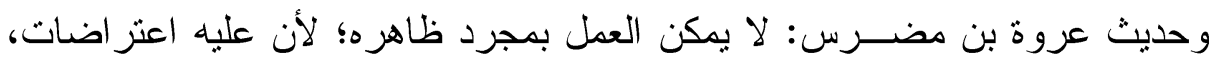

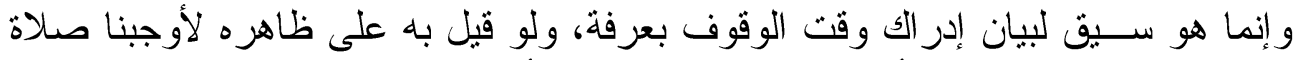

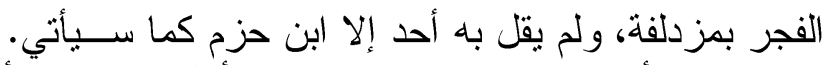

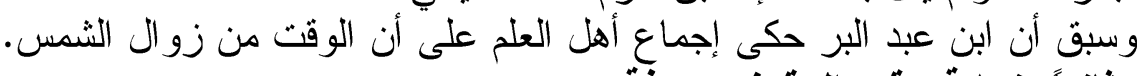

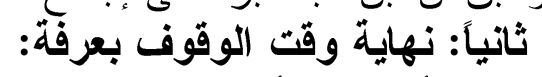

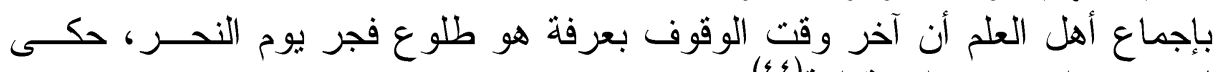

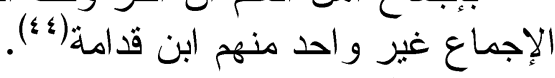

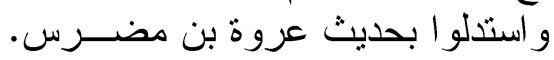

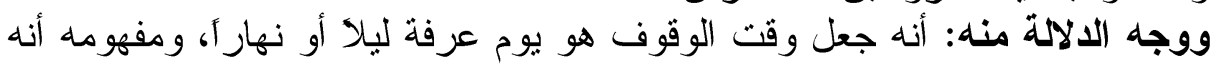

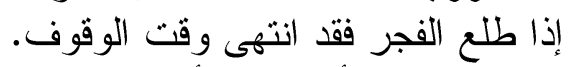

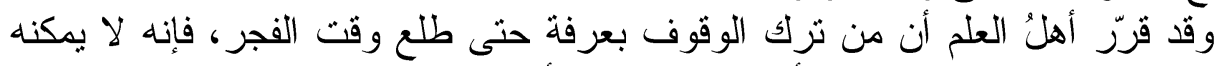

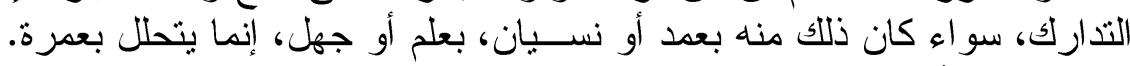

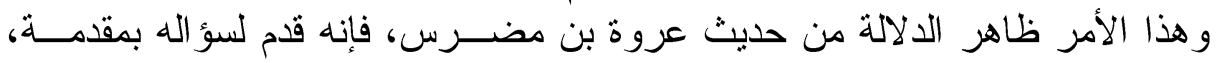

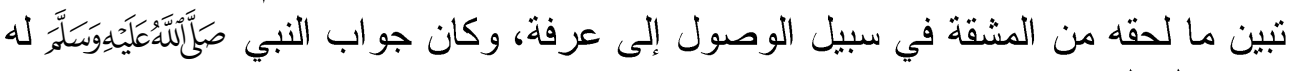

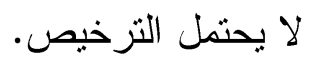

و أما كونه يتحلل بعمرة: فلأن الحج قد فاته، فيأخذ أحكام الفوات، ويتحلل بعمرة.

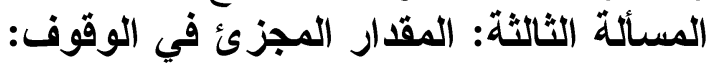

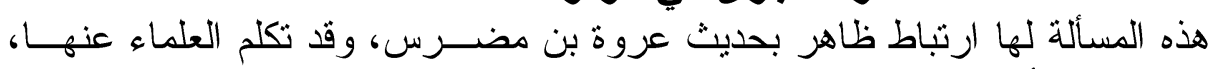
وخلاصة كلامهم أن يقال: الوقوف المباط بعرفة بعة له اله حالات

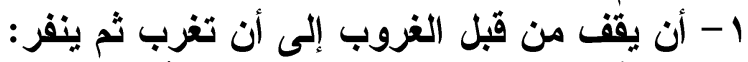

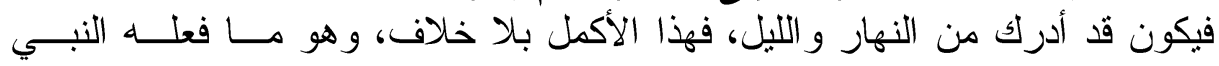

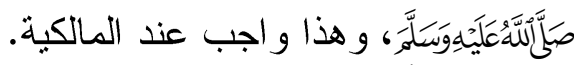
r

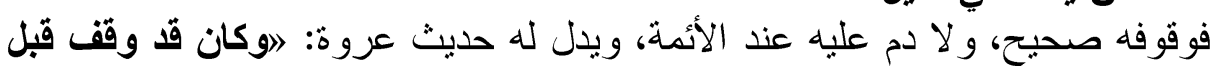

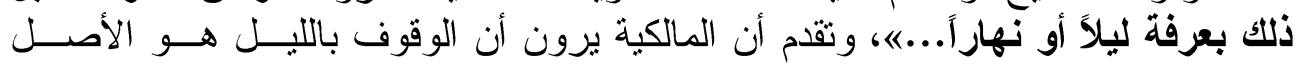

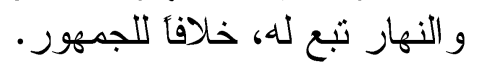


حوليات آداب عين شمس - المجلد 9؛

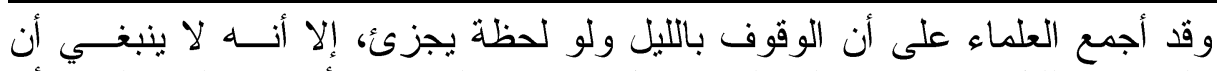

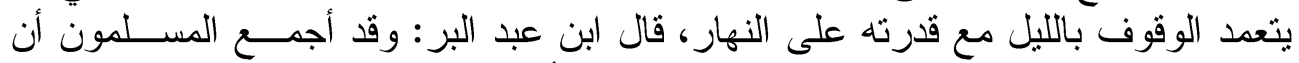

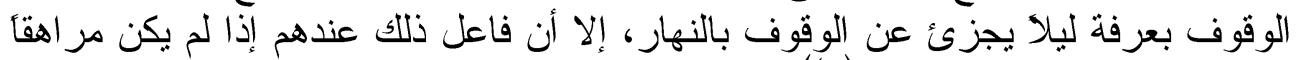

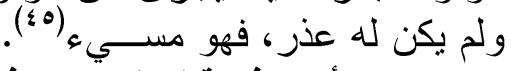

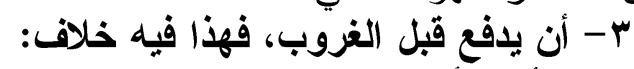

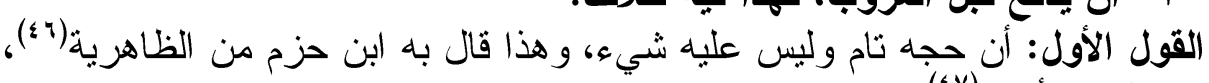

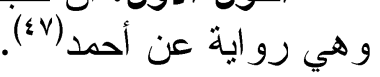

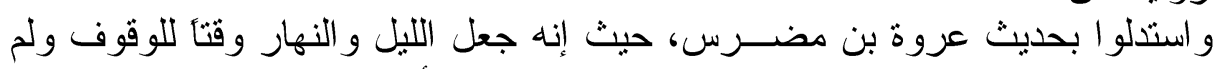

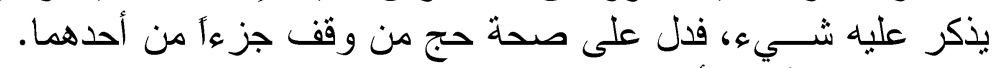

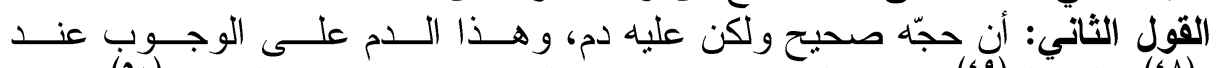

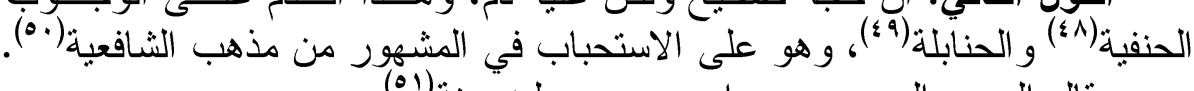

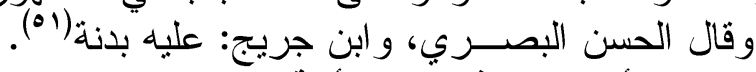

واستدل أصحاب هذا القول بأدلة منها:

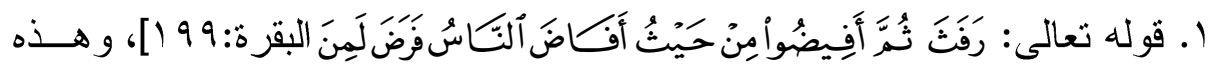

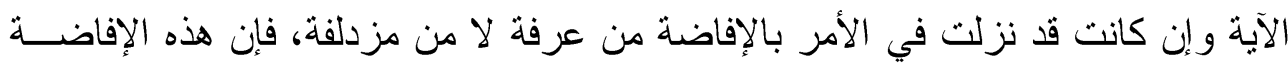

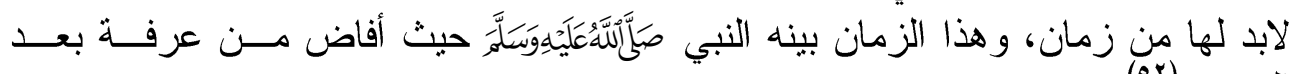

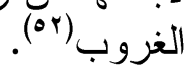

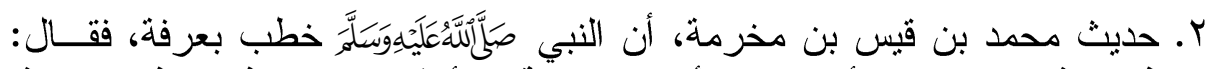

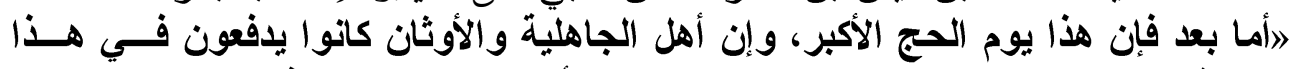

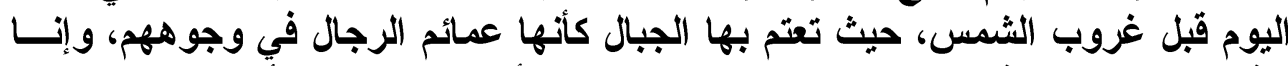

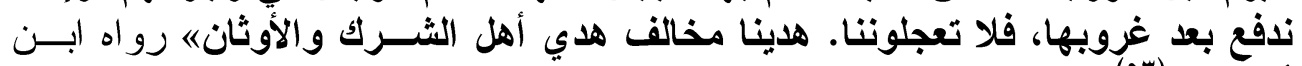

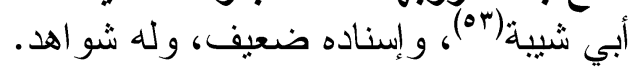

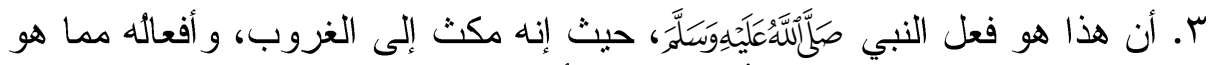

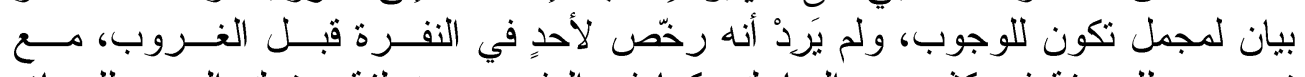

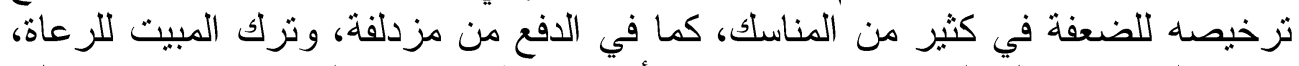

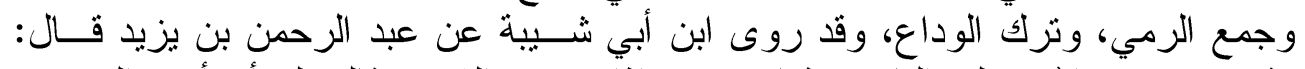

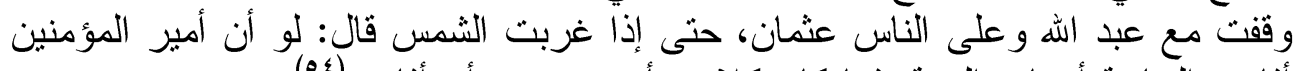

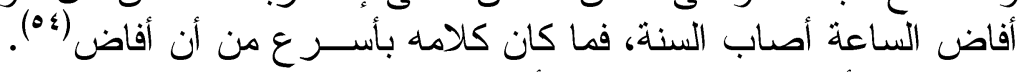

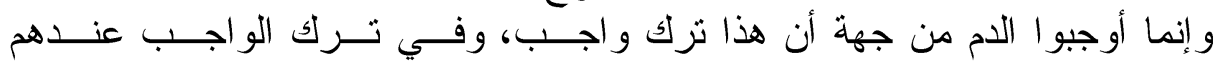
-كما هو معلوم- دمُ. القول الثالث: أن حجه لا يصتح حتى يؤدي شـيـأ من الوقوف بالليل، وبهـــا قـال المالكية (00).

واستدلوا بآثار عن الصحابة منها:

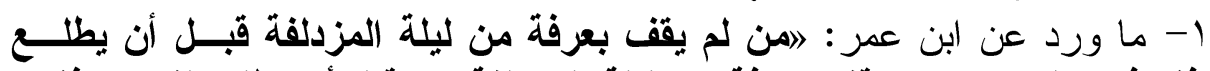

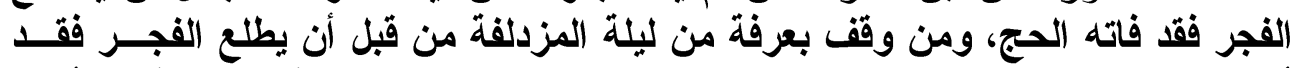

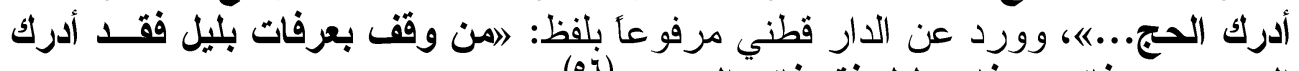

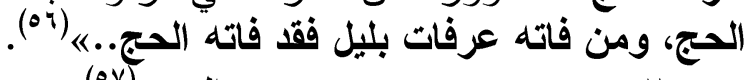

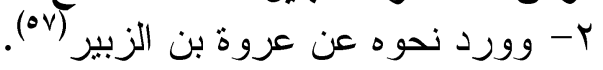

و الأقرب -و الله أعلم-: أن الوقوف بن في عرفة إلى الليل واجب، لما سبق من الأدلة، 


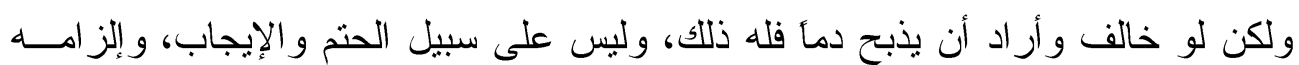

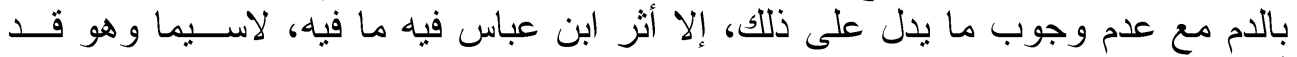

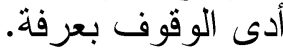

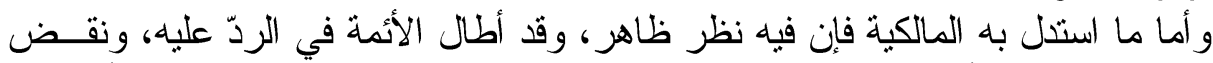

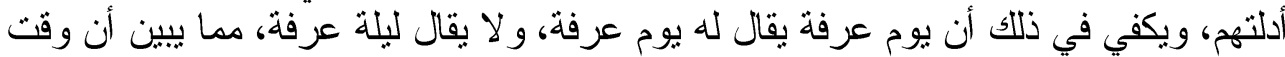

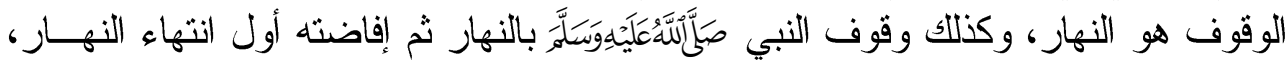

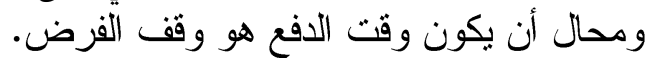

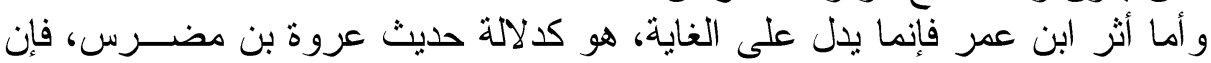

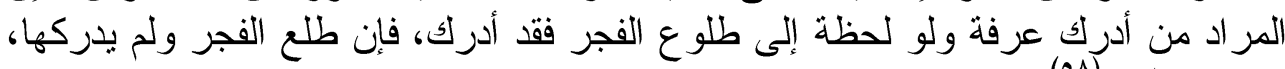

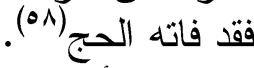

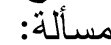

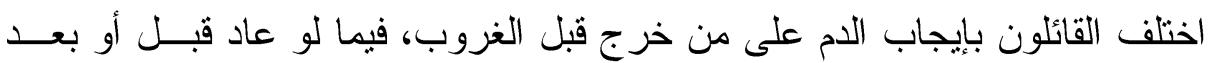

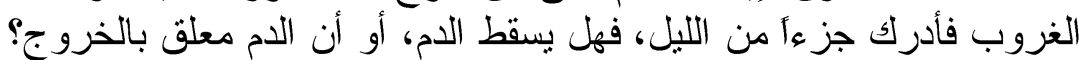

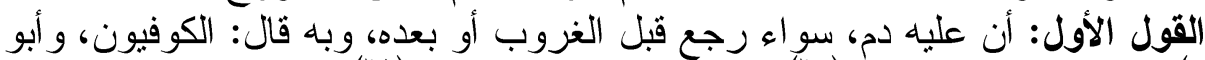

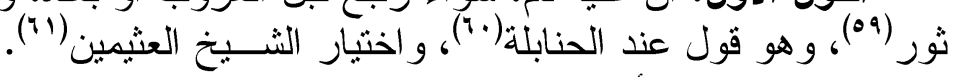

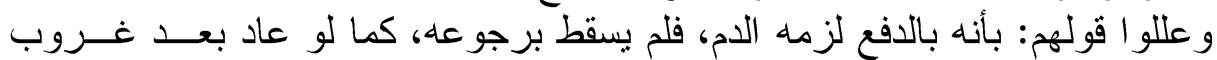
الشمس، فعندهم أن مجرد الدفع مخالفة.

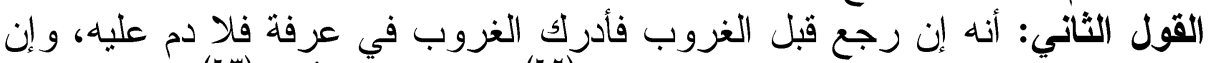

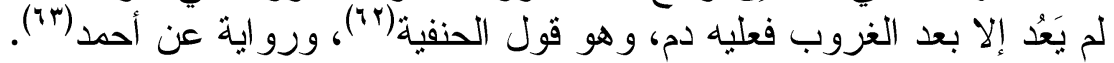

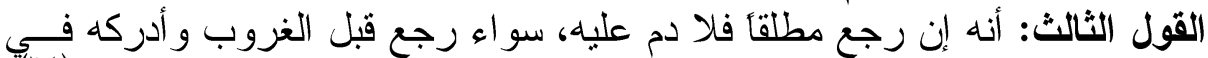

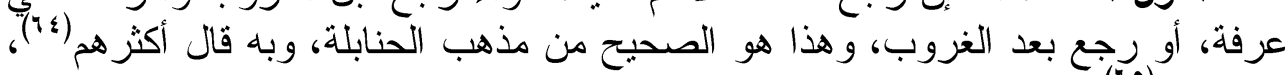

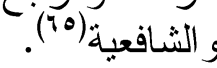
وينبغي أن ينباه إلى أن بعض أهل العلم استثى من ذلافك كله:

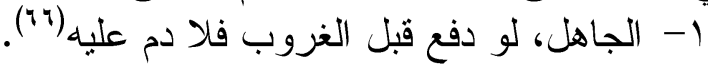

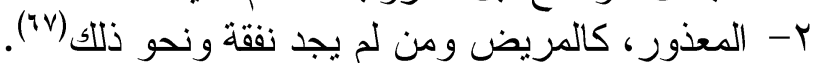
المسألة الر ابعة: هل يشترط أن يعلم أنه وقف بعرفة، أم يصح وقوفه ولو لم لم يعلم أنها المر اد بهذه المسألة: لو أن رجلا مر بعرفة ولم يعلم أنها هي عرفة، فهل يعد وقوفه

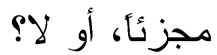

القول الأول: أنه يعتبر مجزئأ، وبهذا قال الأئمة الأربعة.

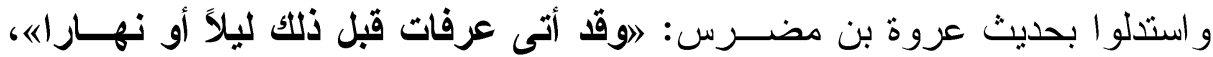

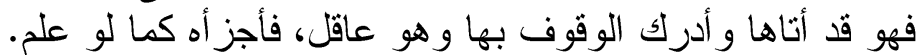

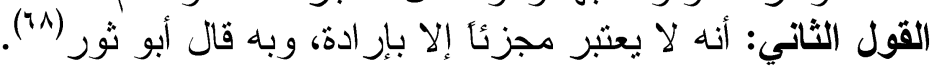

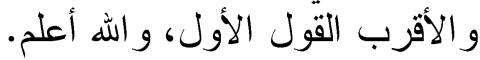




\section{المسائل المتعلقة بالمبيت بمزدلفة}

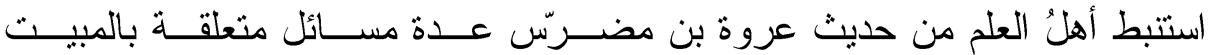
بالمزدلفة، و أهم هذه المسائل ما يلي: المئي المسألة الأولى: حكم المبيت بمزدلفة: المئل

اختلف أهل العلم في حكم المبيت بمزدلفة على بلى ثلاثثة أقو ال:

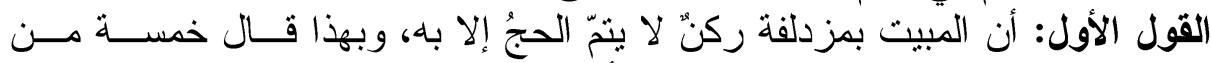

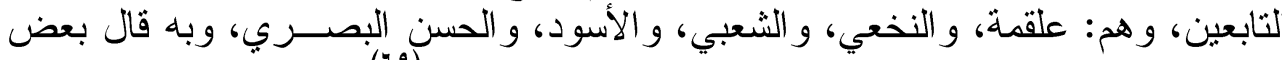

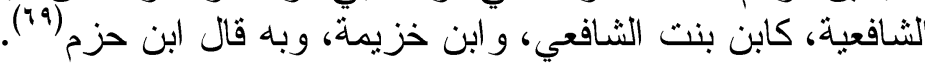

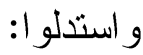

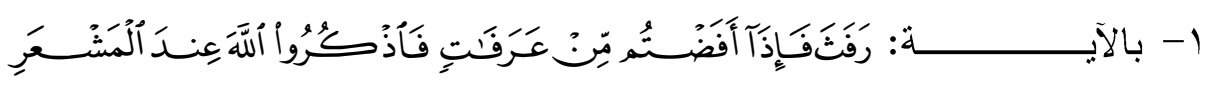

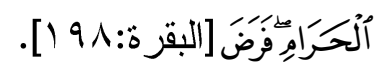

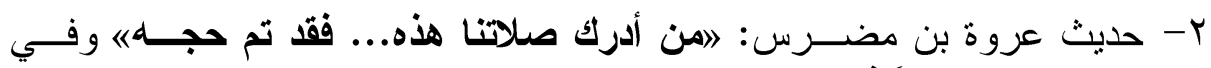

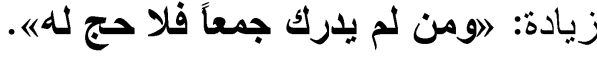

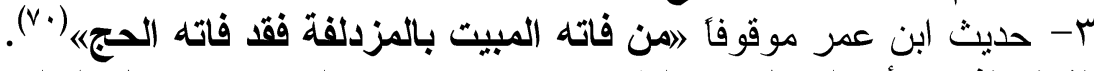

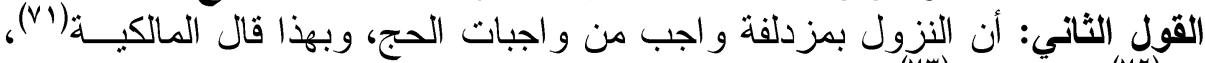
و الحنابلة (VT)، و الثافعية (VT). واستدلوا:

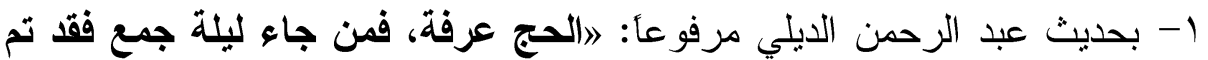

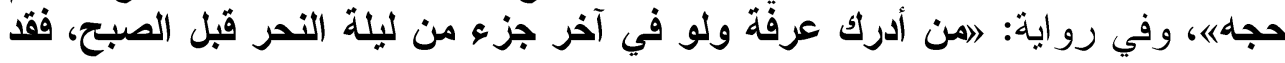

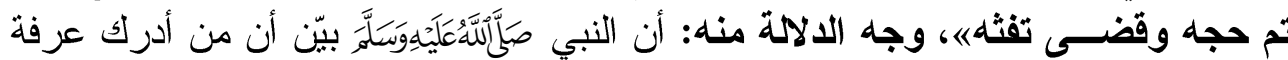

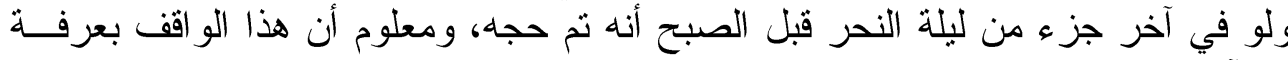

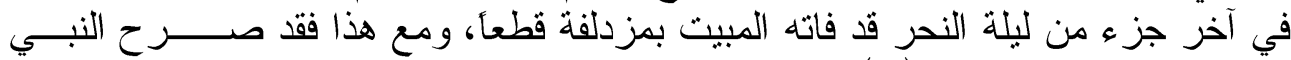

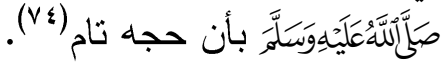
ץ- حديث عروة بن مضـــرس، وقالو ا: أنه لا بدل على على الركنية؛ لأن المنطوق فيه

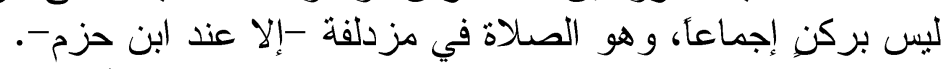

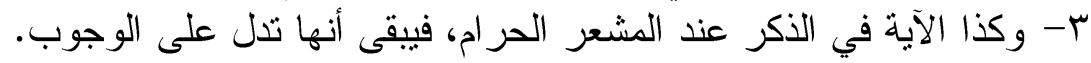

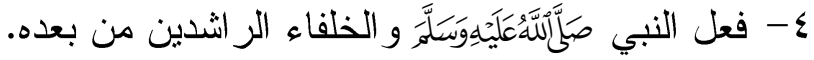

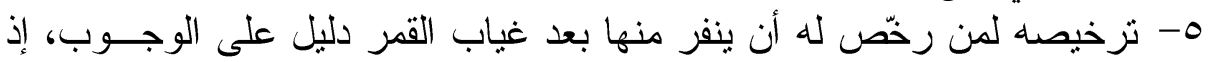
الرخصة لا تكون إلا في مقابل العزيمة.

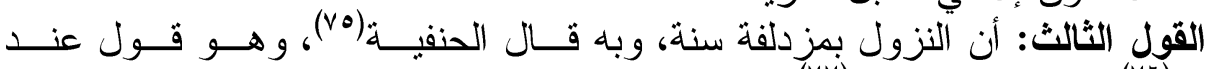

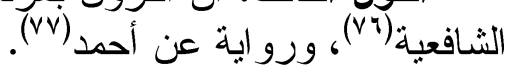

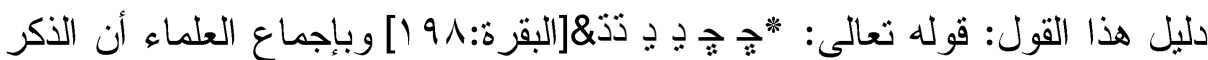

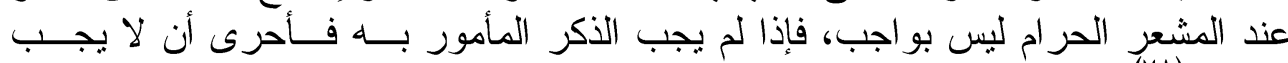

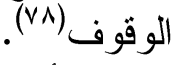

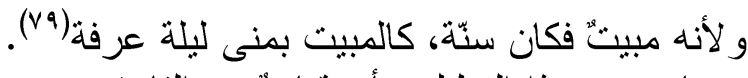

$$
\begin{aligned}
& \text { ويجاب عن هذا التعليل: بأنه قباس" مع الفارق. }
\end{aligned}
$$

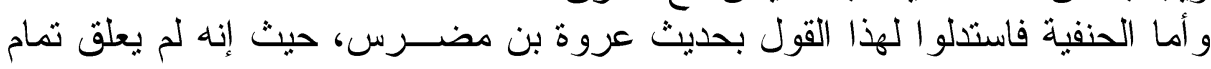




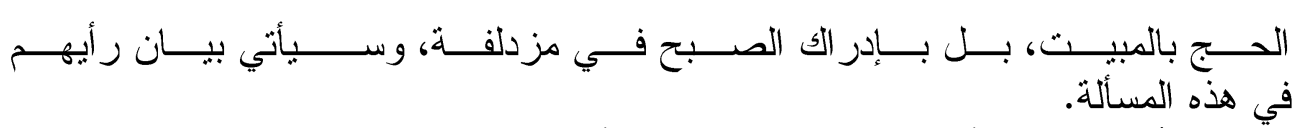
و الأقرب -و الله أعلم- القول الثاني، وهو أن المبيث بمزدلفة واجب مــن و اجبــات الحج، لما سبق ذكره من الأدلة.

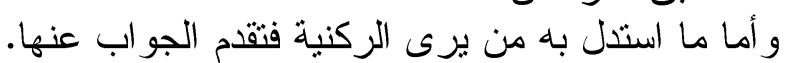

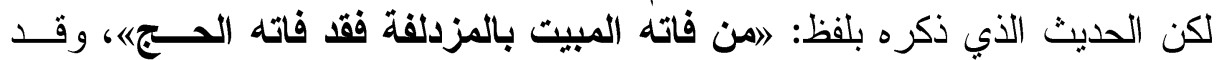

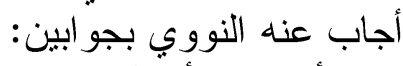

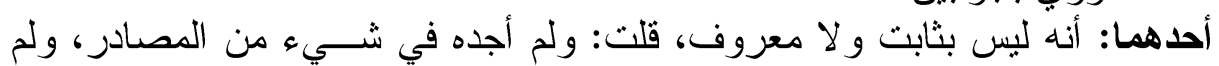

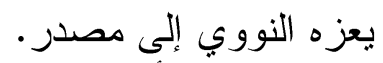

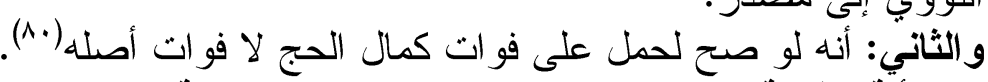

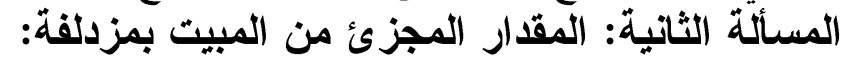

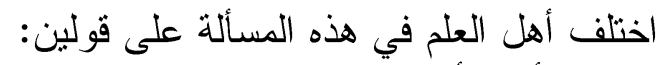

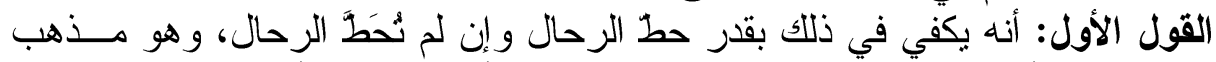

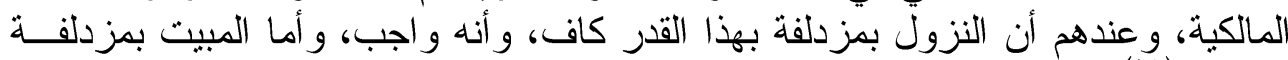

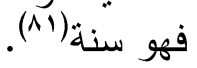

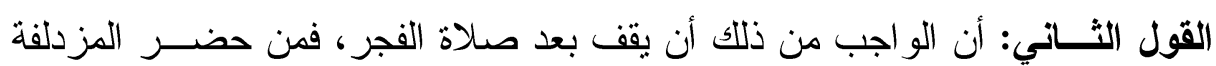

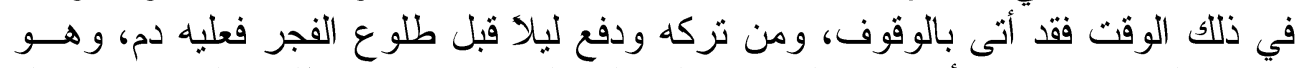

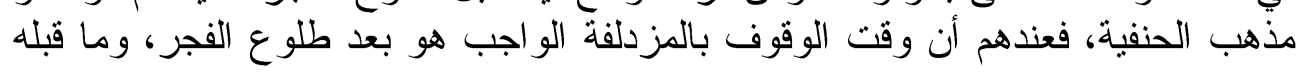

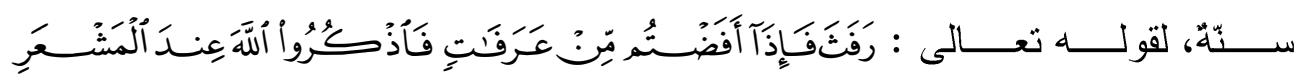

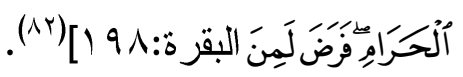

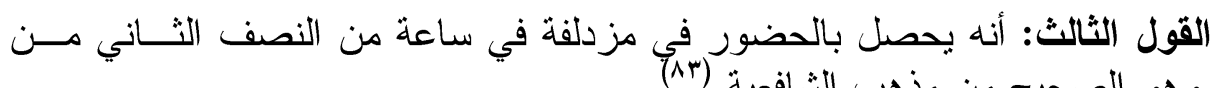

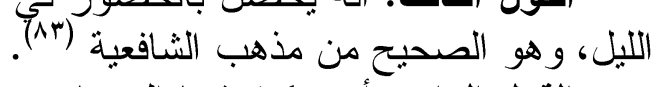

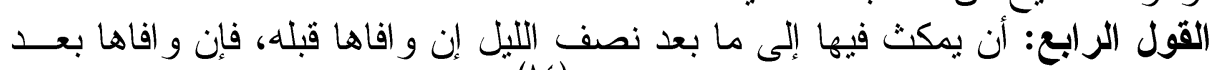

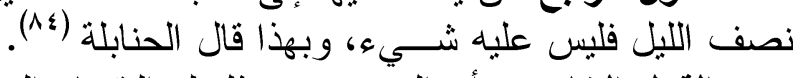

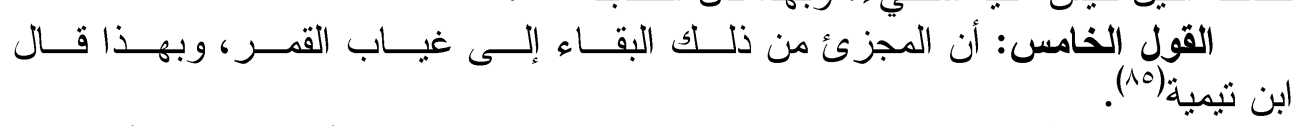

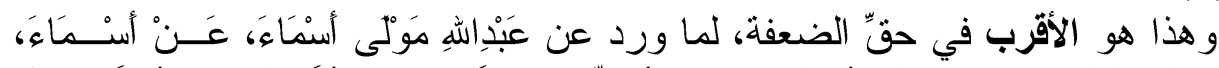

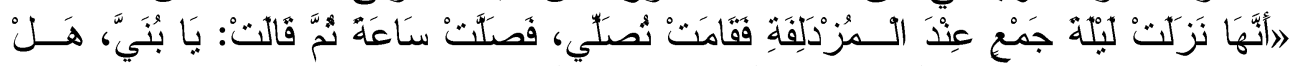

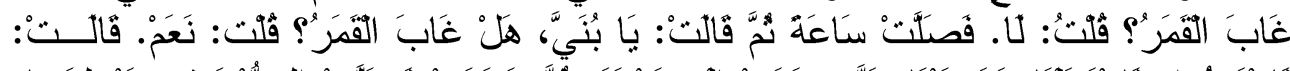

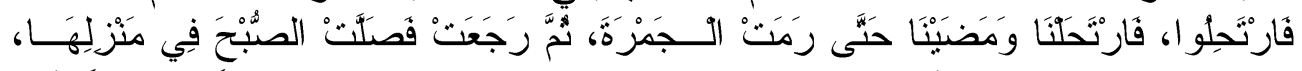

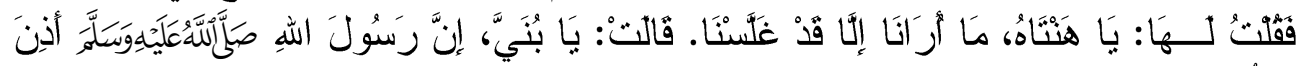

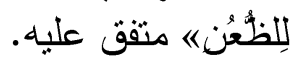

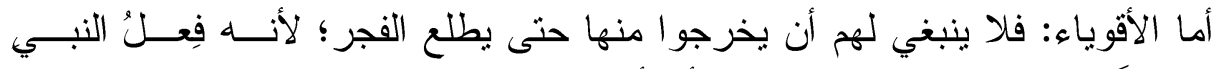

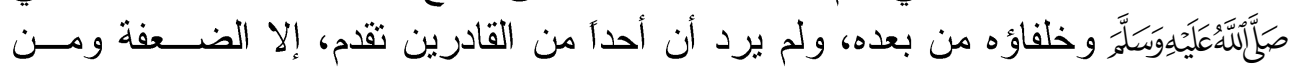

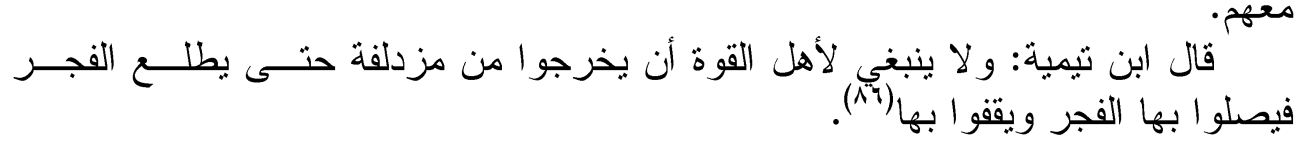




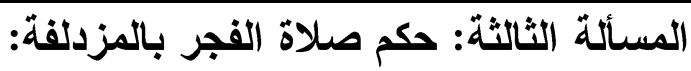

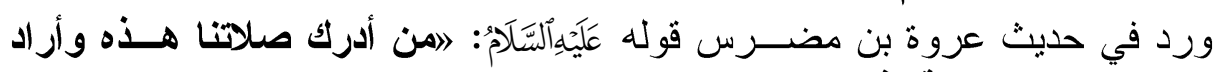
بها صلاة الفجر بالمزدلفة، فقد تم حجهاه.

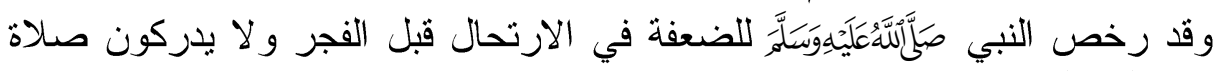

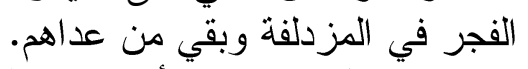

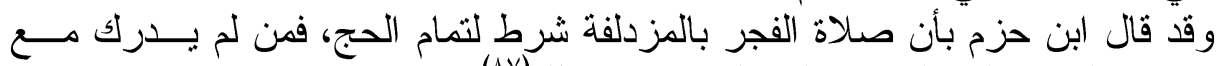

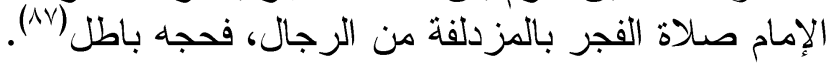

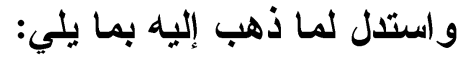

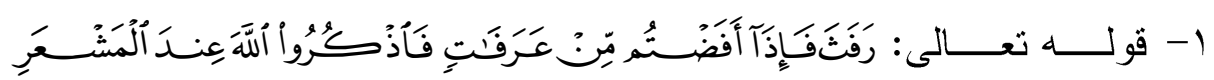

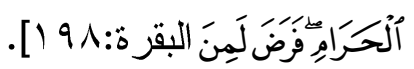

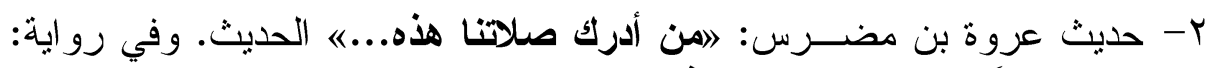

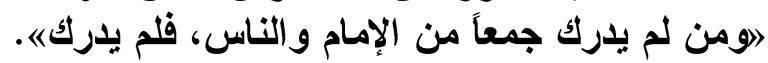

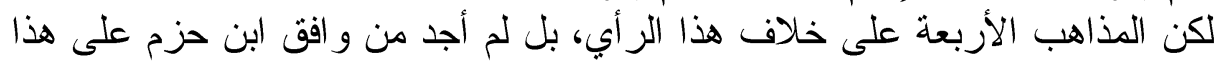

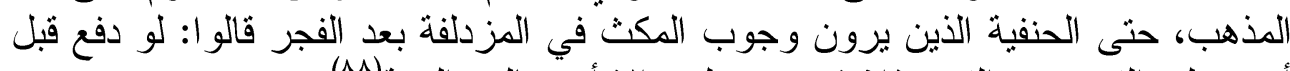

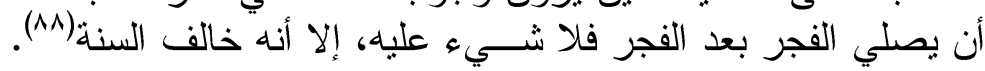

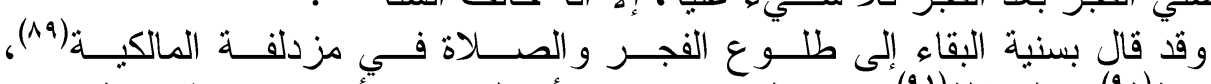

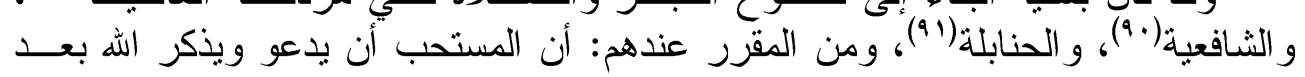

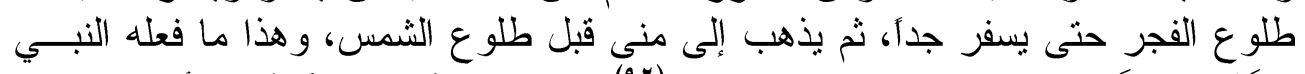

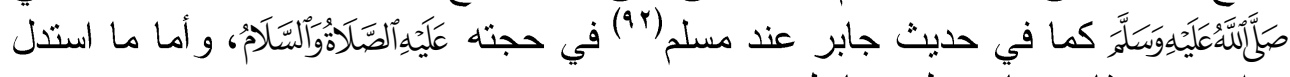

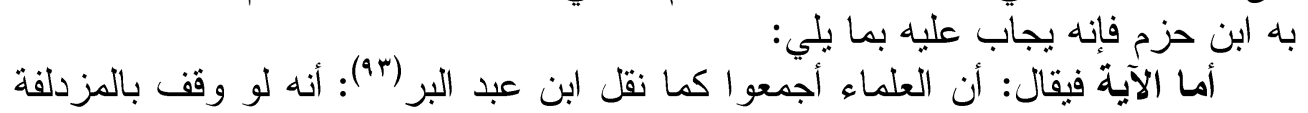

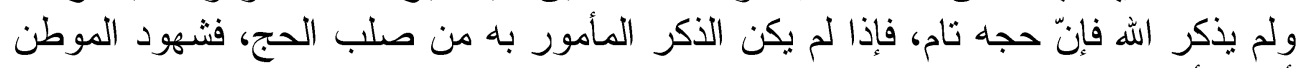
أولى بأن لا يكون كنالك.

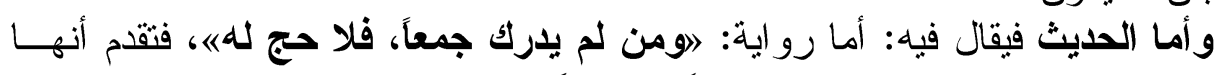

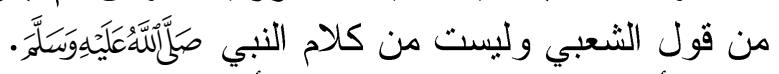

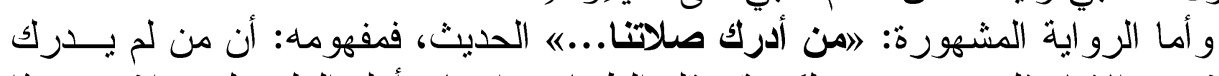

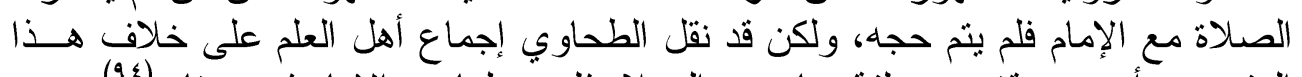

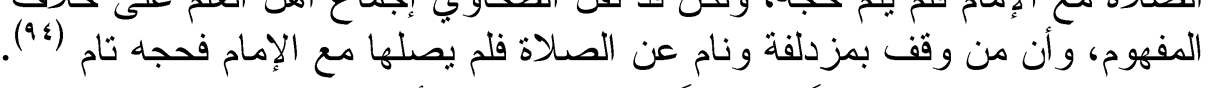

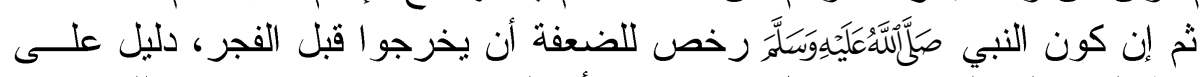

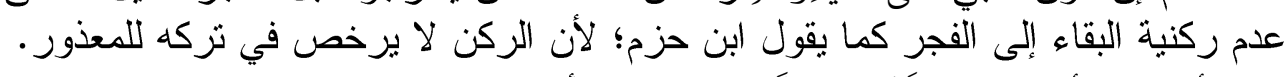

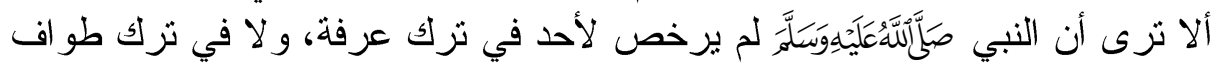

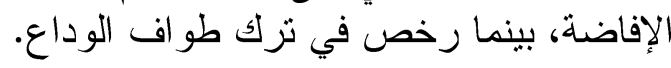




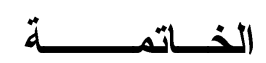 \\ الحمد الله وحده، و الصلاة و السلام على من لا نبي بعده.}

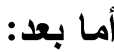

فأحمد الله سبحانه على أن بسـر إتمام هذا البحث، و أسأله سبحانه أن يجعله خالصاً لوجهه، وأن بنفع به كاتبه ومن الهائ على ان عليه.

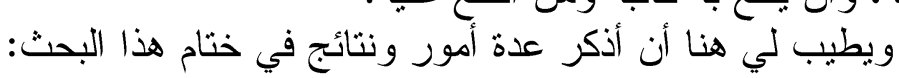

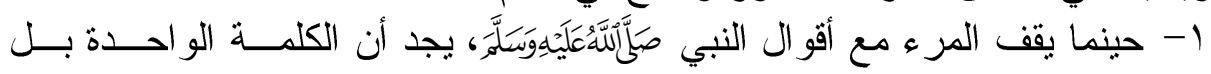

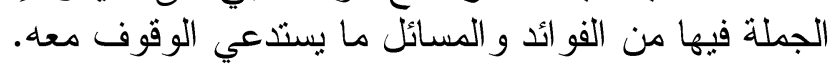

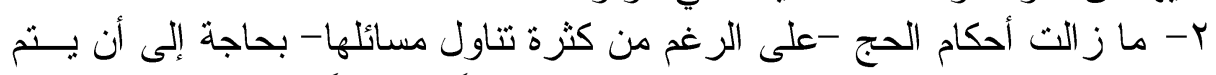

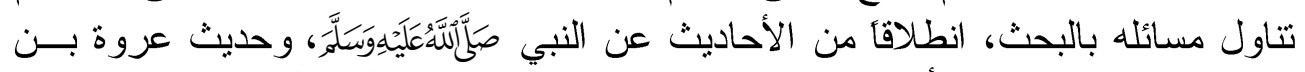

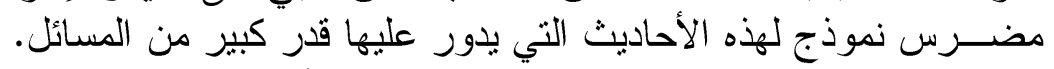

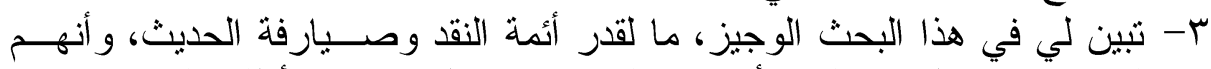

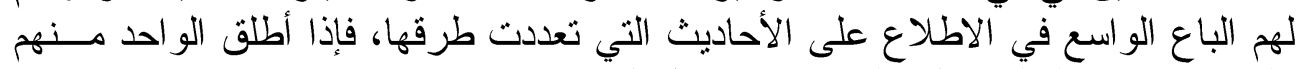

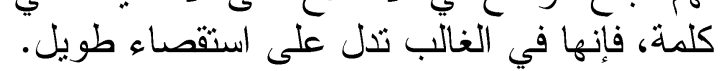

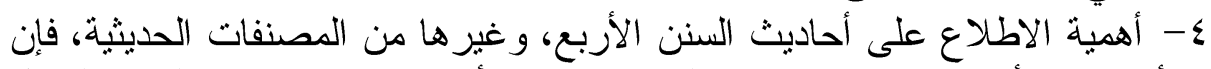

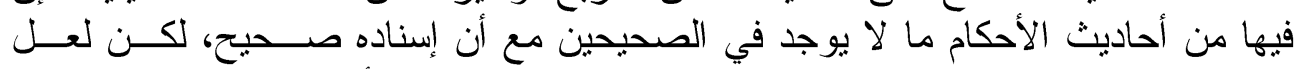

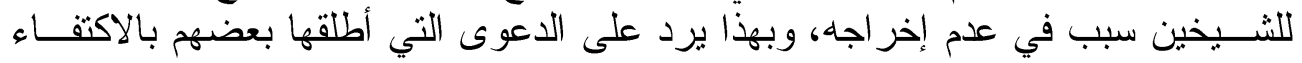
بالصحيحين.

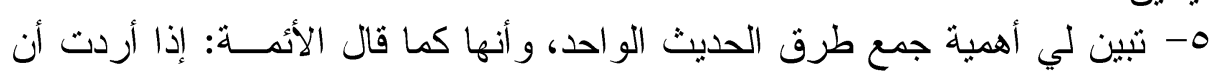

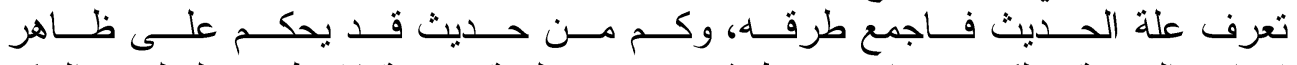

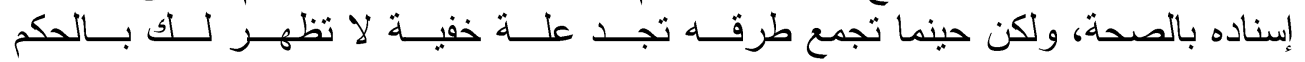
بالمجرد على الإسناد.

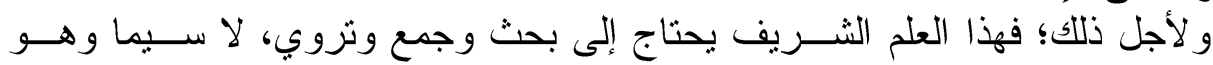

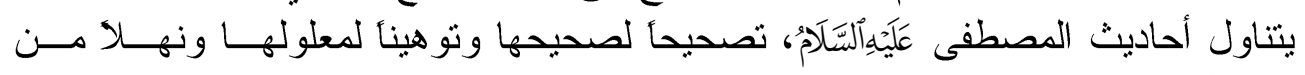

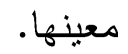
هذا؛ و أسال الله أن يوفقنا للعلم النافع، والإخلاص في القول و العمل.

وصلى الله وسلم على نبينا، وآله وصحبه أجمعين. 


\section{Abstract \\ The hadith of urwa bin Mudars on Hajj, anarration and Knowledge By Mansour Mohamed Ali Suqub}

The research revolves around the hadith of Orwa bin Mudras, who is the origin of the rulings of rites, and it included two main chapters, and a conclusion:

\section{Chapter One:}

Al-Hadith Al-Hadithi, and it included:

The first topic: translation of modern companions.

The second topic: Translations of Hadith narrators.

The third topic: In the graduation of the hadith.

The fourth topic: Judgment on the hadith

Chapter II:

Juristic consideration, and included:

The fifth topic, jurisprudential issues deduced from the hadith.

Conclusion:

It included search results.

\begin{tabular}{|c|}
\hline 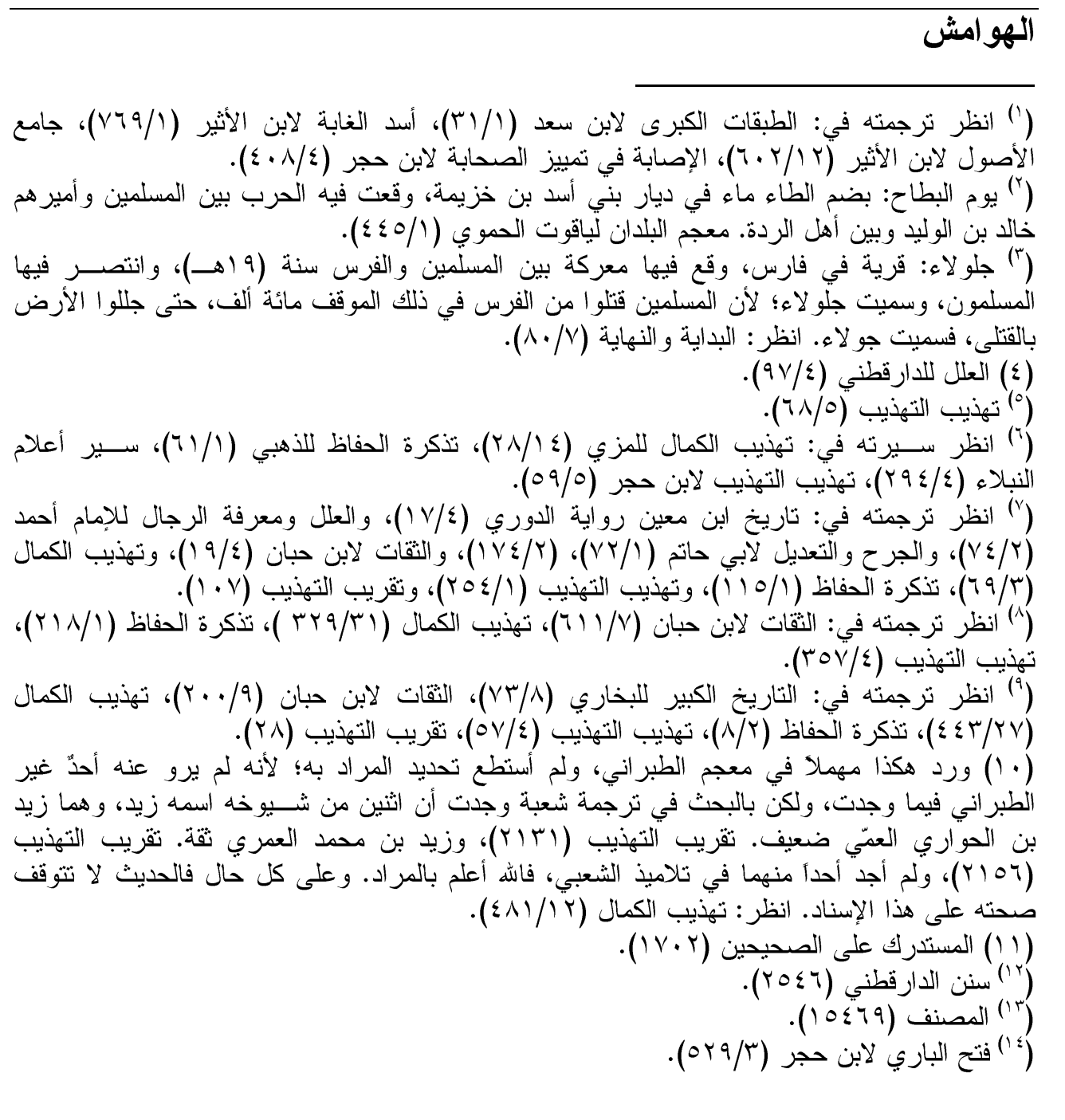 \\
\hline
\end{tabular}




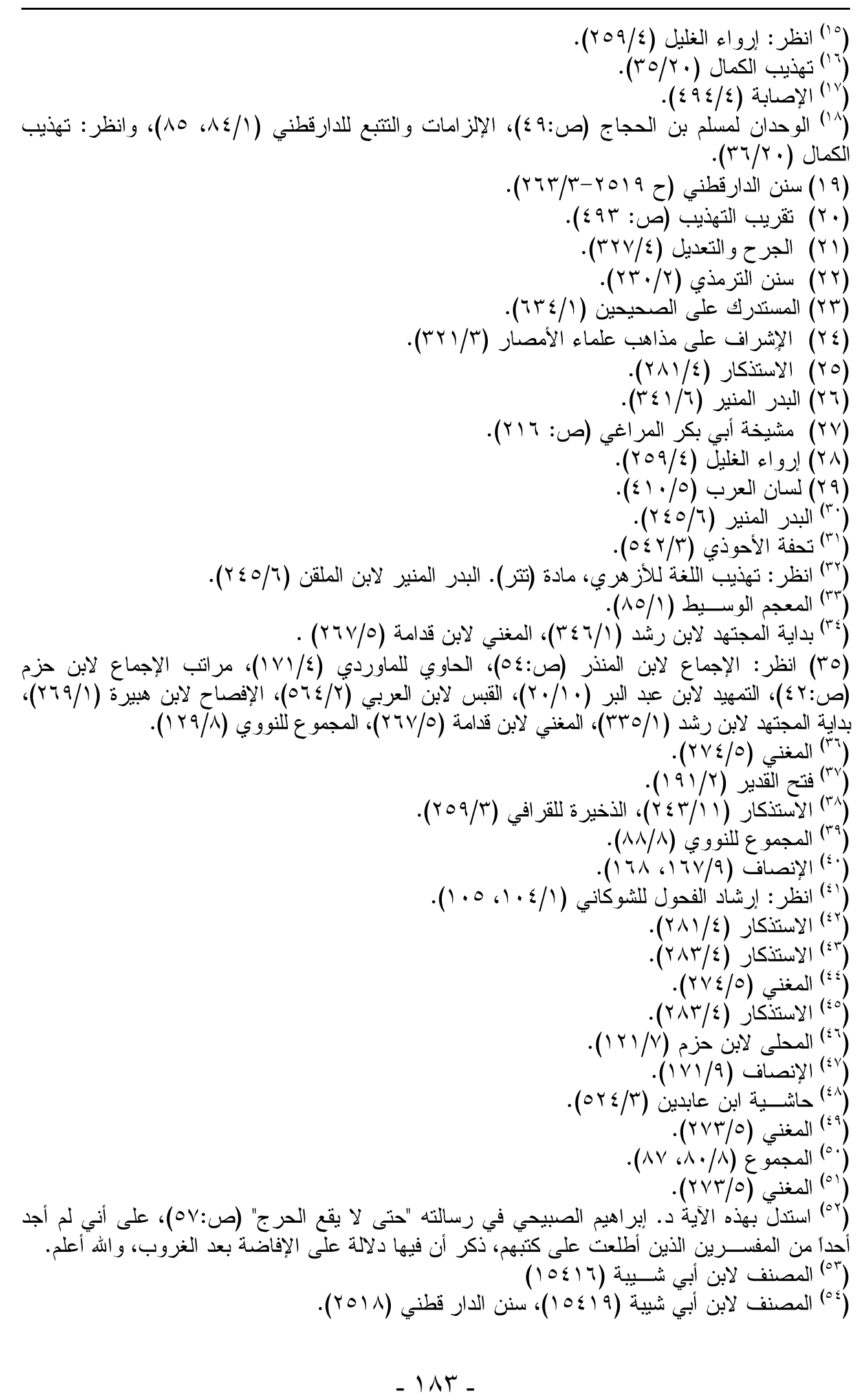




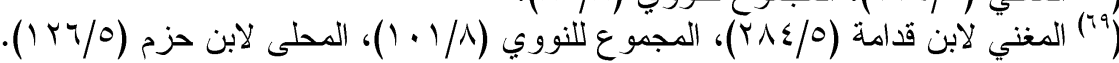

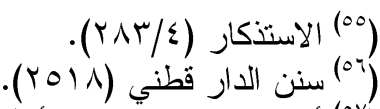

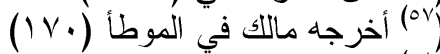

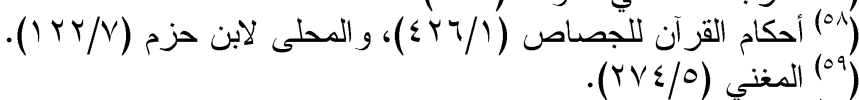

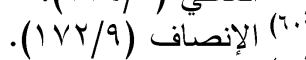

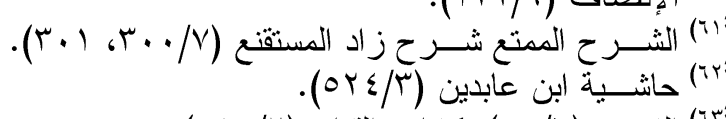

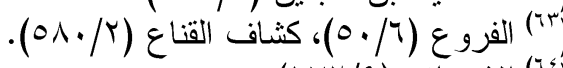

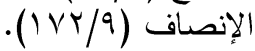

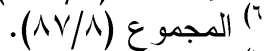

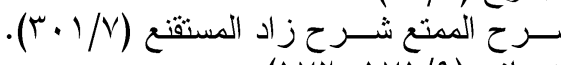

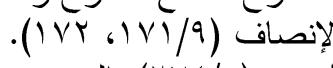

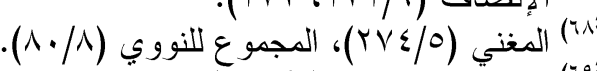

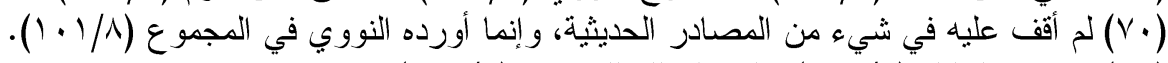

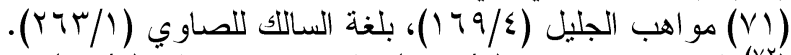

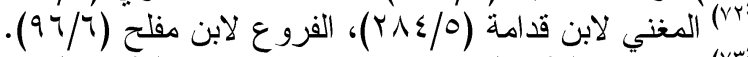

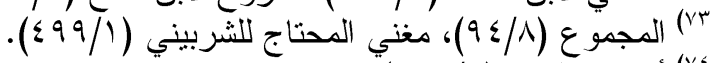

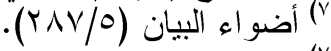

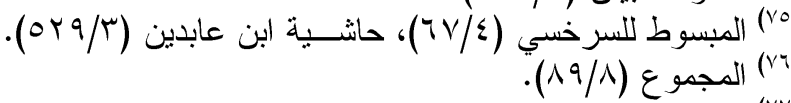

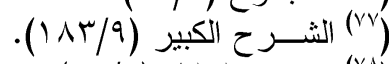

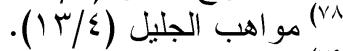

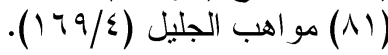

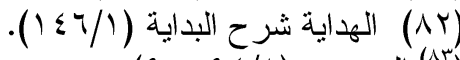

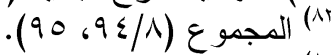

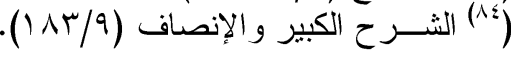

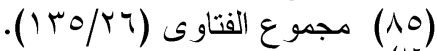

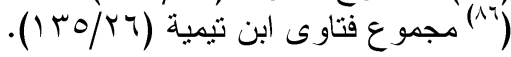

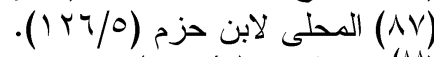

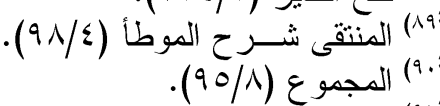

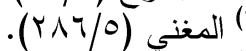

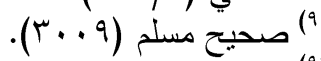

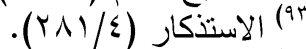

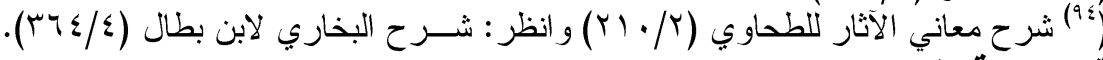

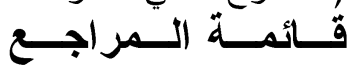

(Y) أحكام القران لأبي بكر الجصاص، المكتبة التجارية، مر اجعة صدقي جميل.

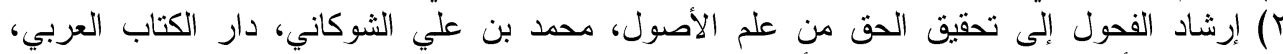

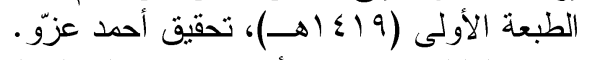
r) إرو اء الغليل في تخريج أحاديث منار السبيل، لمحمد ناصـر الدين الألباني، المكتب الإسلامي، الطبعة 
الثانية (0. ـ أهـ). §) الاستخكار لابن عبد البر النمري، دار الكتب العلمية - بيروت، الطبعة الأولى (ابكأهـ)، تحقيق:

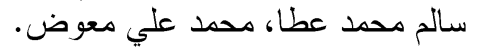
0) الإصابة في تمييز الصحابة، لابن حجر العسقلاني، تحقيق: علي محمد البجاوي، دار الجيل، الطبعة

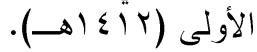

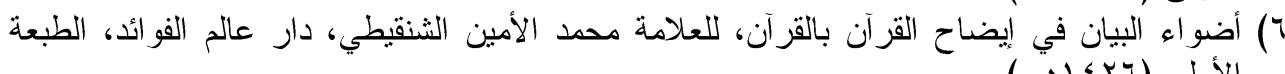

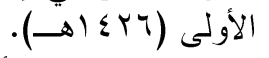
V) الإلزامات و التتبع، لأبي الحسن الدارقطني، دار الكتب العلمية، الطبعة الثانية، تحقيق: مقبل بن هادي

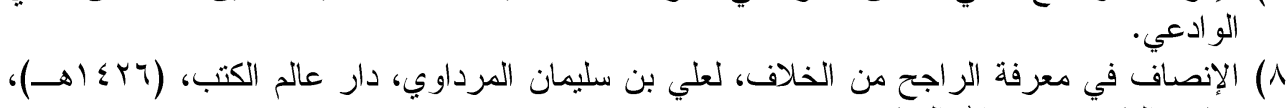

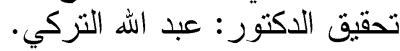

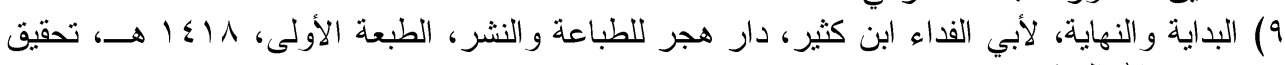

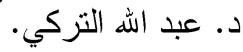

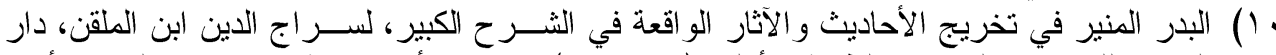

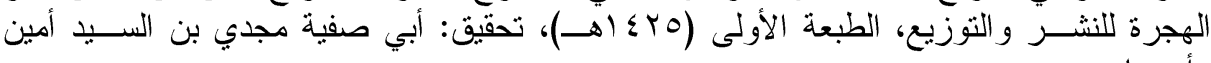

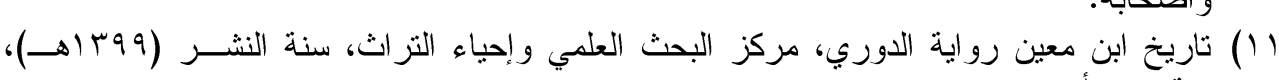

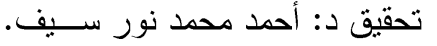
r ( ) التاريخ الكبير، للإمام البخاري، دائرة المعارف العثمانية، حيدر آباد - الدكن، طبع تحت مر اقبة: محمد عبد المعيد خان.

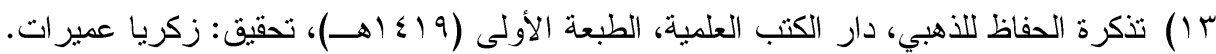

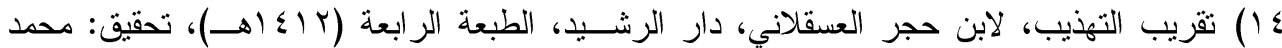
عو امة.

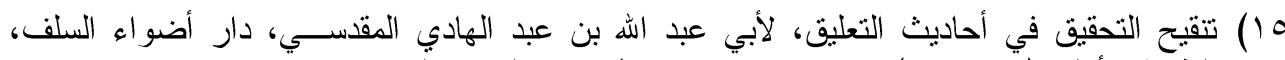

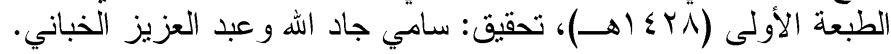

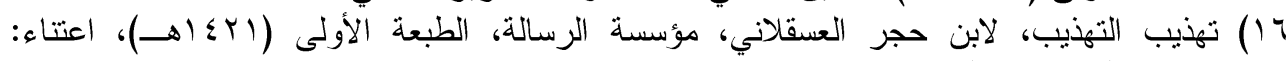

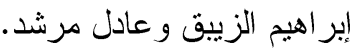

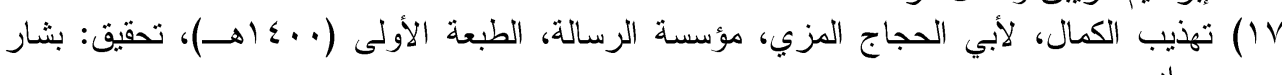
عو اد.

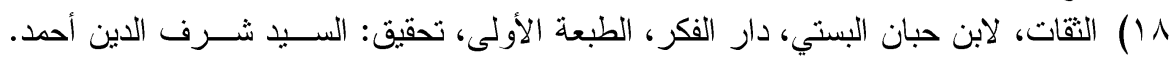

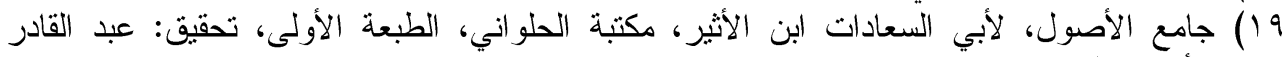

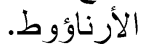

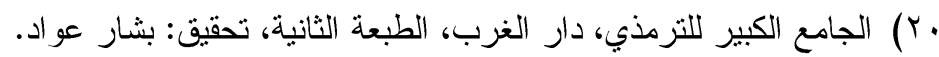

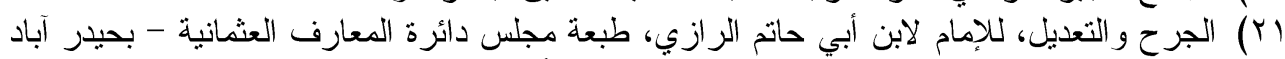

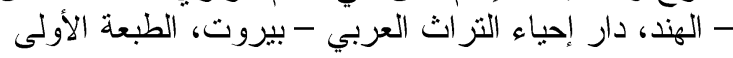

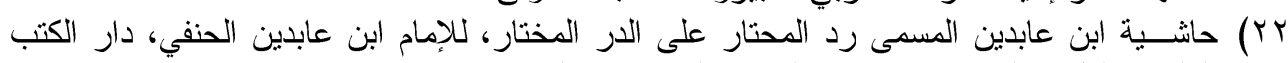

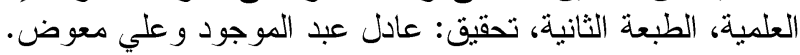

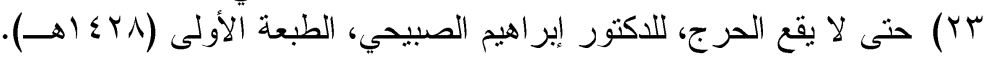

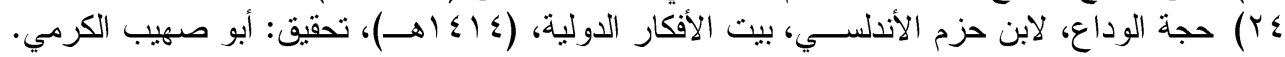

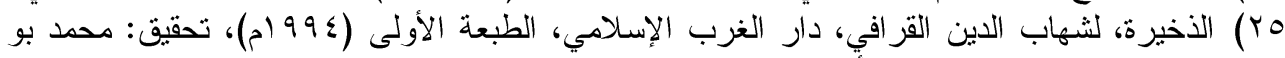

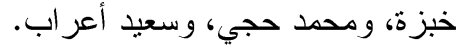

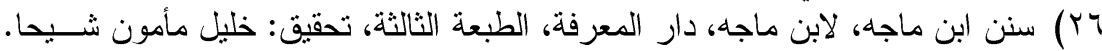
سنن أبي داود، للإمام سليمان بن الأشعث السجستاني، دار الطعة الكتاب العربي - بيروت. 
آر سنن الدارقطني، للإمام الدارقطني، مؤسسة الرسالة، الطبعة الأولى، تحقيق: شعيب الأرناؤوط

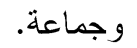
9 سن الدن الدارمي، لأبي محمد الدارمي، دار الكتاب العربي، الطبعة الأولى، تحقيق: فواز زمرلي وخالد السبع العلمي.

•r) السنن الكبرى، لأبي بكر البيهقي، مكتبة دار الباز، تحقيق: محمد عطا.

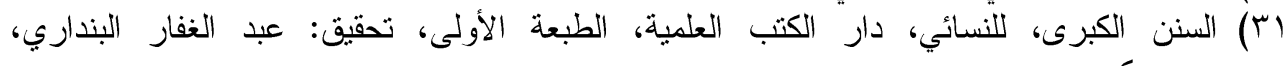

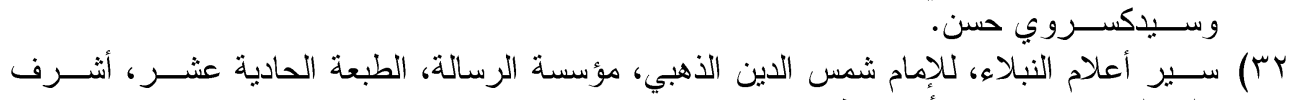

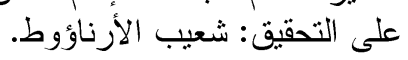

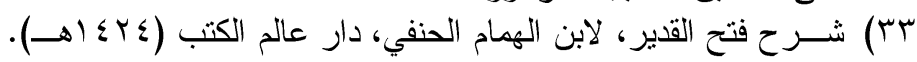

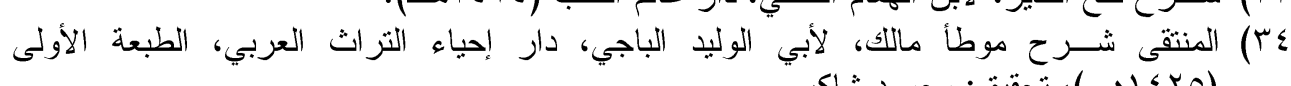

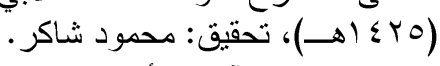

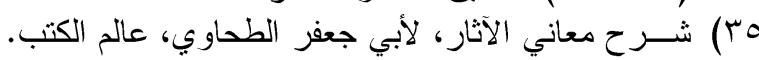

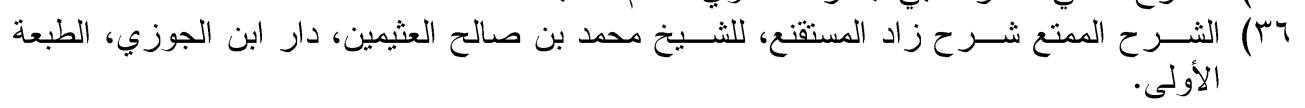
صالم الأحيح ابن حزيمة، لمحمد بن إسحاق بن خزيمة، المكتبة الإسلامية، تحقيق د: محمد مصطفى

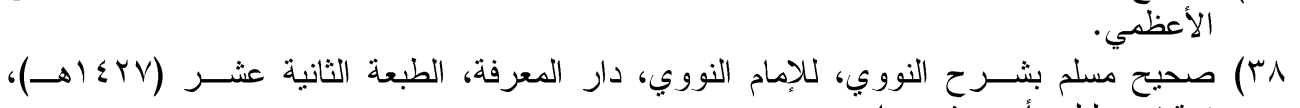

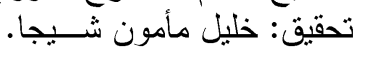

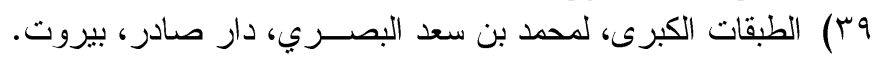

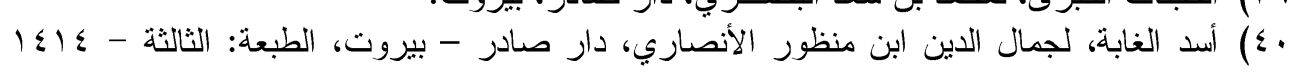
اء) العلل ومعرفة الرجال، لأحمد بن حنبل، المكتب الإسلامي ودار الخاني، الطبعة الأولى، تحقيق:

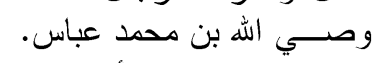
r乏) العلل الَّ اردة في الأحاديث النبوية، لأبي الحسن الدارقطني، دار طيبة، الرياض، الطبعة الأولى،

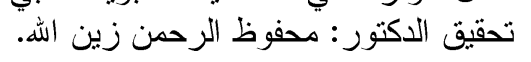
rـأ) غوث المكدود بتحريج منتقى ابن الجارود، لأبي إسحاق الحويني، دار الكتاب العربي، سنة الطبع

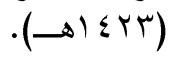
ـ §) فتح الباري، لابن حجر العسقلاني، المطبعة السلفية، ترقيه: محمد فؤاد عبد الباقي.

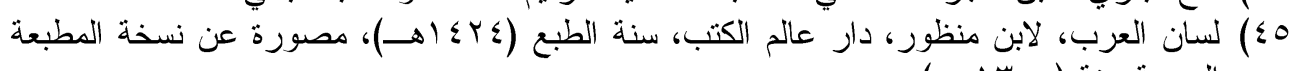

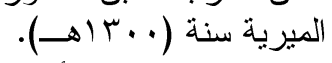
ד؟) المجتبى من السنن، لأبي عبد الرحمن النسائي، مكتب المطبو عات الإسلامية، الطبعة الثانية، تحقيق: عبد الفتاح أبو غدة. الفنز

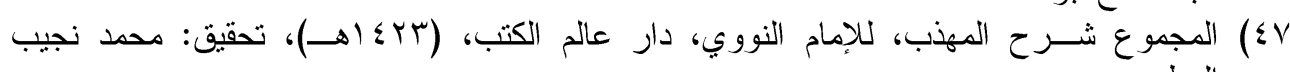

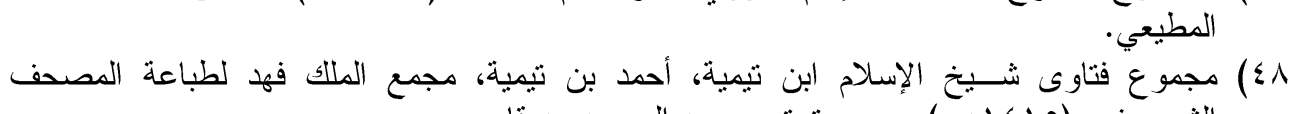

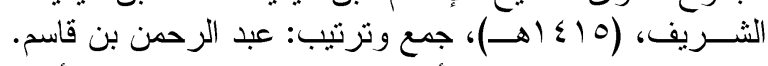

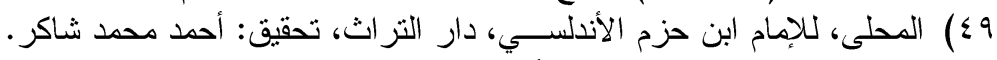

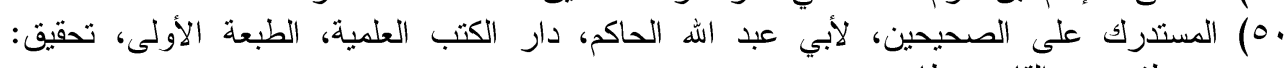
مصطفى عبد القادر عطا. 10) مسند أبي بعلى، لأبي بعلى الموصلي، دار المأمون للتراث، الطبعة الأولى، تحقيق: حسـين سليم ro ورفاقه، للإمام أحمد بن حنبل الثـيباني، مؤسسة الرسالة، الطبعة الثانية، تحقيق: شعيب الأرناؤوط 
بم) مسند الحمبدي، لأبي بكر الحمبدي، دار الكتب العلمية ومكتبة المتنبي، تحقيق: حبيب الرحمن

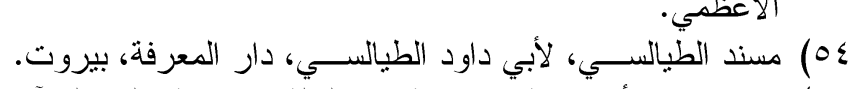

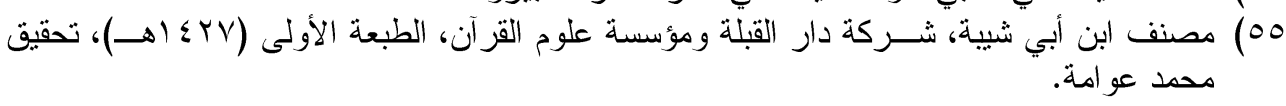

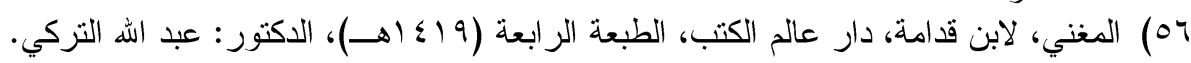

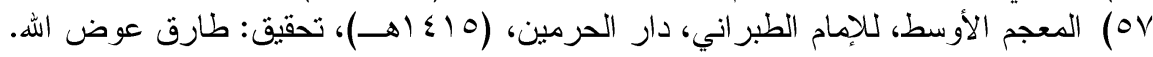

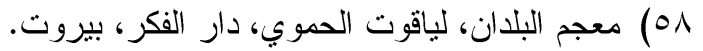

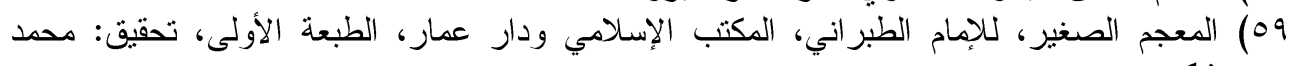

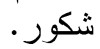

• ؟) المعجم الكبير ، للإمام الطبر اني، مكتبة ابن تيمية، القاهرة، تحقيق: حمدي السلفي.

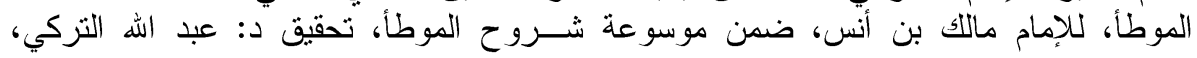

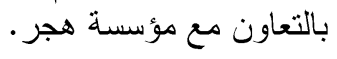

